\title{
Vegetation and Climate of Maritime Canada 6000 Years BP: A
}

\section{Synthesis}

\author{
La végétation et le climat dans les Maritimes à $6000 \mathrm{BP}$ : une \\ synthèse
}

\section{Vegetation und Klima in den Küstenprovinzen Ostkanadas 6000 Jahre v.u.Z.: Eine Synthese}

\author{
Hélène Jetté et Robert J. Mott
}

Volume 49, numéro 1, 1995

La paléogéographie et la paléoécologie d’il y a 6000 ans BP au Canada Paleogeography and Paleoecology of 6000 yr BP in Canada

URI : https://id.erudit.org/iderudit/033034ar

DOI : https://doi.org/10.7202/033034ar

\section{Aller au sommaire du numéro}

\section{Éditeur(s)}

Les Presses de l'Université de Montréal

\section{ISSN}

0705-7199 (imprimé)

1492-143X (numérique)

\section{Découvrir la revue}

Citer cet article

Jetté, H. \& Mott, R. J. (1995). Vegetation and Climate of Maritime Canada 6000 Years BP: A Synthesis. Géographie physique et Quaternaire, 49(1), 141-162. https://doi.org/10.7202/033034ar

\section{Résumé de l'article}

On a fait la reconstitution des conditions environnementales des Maritimes dans le cadre d'une synthèse des paléoenvironnements au Canada à $6000 \mathrm{BP}$. Dix nouveaux sites, comprenant trois séquences complètes et sept courtes séquences couvrant la période de $6000 \mathrm{BP}$, ont été ajoutés aux données polliniques existantes sur la région. La végétation dominante à $6000 \mathrm{BP}$ au Nouveau-Brunswick est celle de la forêt mixte de conifères et de feuillus à prédominance de pin, surtout le pin blanc (Pinus strobus) au nord-ouest, et celle de la forêt mixte de conifères et de feuillus dominée par la pruche (Tsuga canadensis), au sud et au sud-est. Dans le nord-ouest, le sapin (Abies) a remplacé le pin en altitude et la forêt boréale s'est implantée sur les hautes terres du Nouveau-Brunswick. À 6000 BP, la végétation dominante à l'Île-du-Prince-Édouard et en Nouvelle-Ecosse était celle de la forêt mixte de conifères et de feuillus à prédominance de pruches. L'île du Cap-Breton était couverte par une forêt mixte de conifères et de feuillus dominée par le pin ou le sapin, sauf dans le sud de l'île où la pruche était probablement présente. L'analyse des sites fossilifères montre que le climat chaud et sec de la période de $6000 \mathrm{BP}$ a influencé la composition de la végétation.
Tous droits réservés ㄷ Les Presses de l'Université de Montréal, 1995
Ce document est protégé par la loi sur le droit d'auteur. L’utilisation des services d'Érudit (y compris la reproduction) est assujettie à sa politique d'utilisation que vous pouvez consulter en ligne.

https://apropos.erudit.org/fr/usagers/politique-dutilisation/ 


\title{
VEGETATION AND CLIMATE OF MARITIME CANADA 6000 YEARS BP: A SYNTHESIS*
}

\author{
Hélène JETTÉ and Robert J. MOTT, Geological Survey of Canada, 601 Booth Street, Ottawa, Ontario K1A 0E8.
}

\begin{abstract}
Environmental conditions (vegetation and climate) of Maritime Canada are reconstructed as a regional contribution to a national synthesis on the paleoenvironment of Canada 6000 yr BP. Ten new sites, including three complete sequences and seven short sequences bracketing the 6 ka period, are added to the existing pollen dataset for this region. The vegetation prevalent $6000 \mathrm{yr}$ BP in New Brunswick was a mixed coniferous-deciduous forest with pine, mostly white pine (Pinus strobus) in the northwest, and a mixed coniferousdeciduous forest with hemlock (Tsuga canadensis) in the south and southeast. In the northwest, fir (Abies) replaced pine at high elevations and a boreal forest grew on the New Brunswick Highlands. The dominant vegetation at $6000 \mathrm{yr} \mathrm{BP}$ in Prince Edward Island and Nova Scotia was a mixed coniferous-deciduous forest with hemlock dominating. Cape Breton Island was covered by a mixed coniferous-deciduous forest with pine and/or fir, except for the southern part of the Island where hemlock was probably present. Analysis of the fossil sites indicate that a warm-dry period influenced the composition of the vegetation $6000 \mathrm{yr}$ BP.
\end{abstract}

RÉSUMÉ La végétation et le climat dans les Maritimes à 6000 BP: une synthèse. On a fait la reconstitution des conditions environnementales des Maritimes dans le cadre d'une synthèse des paléoenvironnements au Canada à 6000 BP. Dix nouveaux sites, comprenant trois séquences complètes et sept courtes séquences couvrant la période de $6000 \mathrm{BP}$, ont été ajoutés aux données polliniques existantes sur la région. La végétation dominante à 6000 BP au Nouveau-Brunswick est celle de la forêt mixte de conifères et de feuillus à prédominance de pin, surtout le pin blanc (Pinus strobus) au nord-ouest, et celle de la forêt mixte de conifères et de feuillus dominée par la pruche (Tsuga canadensis), au sud et au sud-est. Dans le nord-ouest, le sapin (Abies) a remplacé le pin en altitude et la forêt boréale s'est implantée sur les hautes terres du Nouveau-Brunswick. À $6000 \mathrm{BP}$, la végétation dominante à l'îledu-Prince-Édouard et en Nouvelle-Écosse était celle de la forêt mixte de conifères et de feuillus à prédominance de pruches. L'île du Cap-Breton était couverte par une forêt mixte de conifères et de feuillus dominée par le pin ou le sapin, sauf dans le sud de l'île où la pruche était probablement présente. L'analyse des sites fossilifères montre que le climat chaud et sec de la période de $6000 \mathrm{BP}$ a influencé la composition de la végétation.
ZUSAMMENFASSUNG Vegetation und Klima in den Küstenprovinzen Ostkanadas 6000 Jahre v.u.Z.: Eine Synthese. Im Rahmen eines regionalen Beitrags zu einer nationalen Synthese der Paläoumwelt Kanadas 6000 Jahre v.u.Z. hat man die Umweltbedingungen (Vegetation und Klima) in den Küstenprovinzen Ostkanadas rekonstruiert. Zehn neue Plätze, darunter drei komplette Sequenzen und sieben kurze Sequenzen der 6 ka Periode, sind den bestehenden Daten zu dieser Region hinzugefügt worden. Die um 6000 Jahre v.u.Z. in New Brunswick vorherrschende Vegetation war ein Mischwald aus Tannen und Laubbäumen mit Kiefer, vor allem Weißkiefer (Pinus strobus) im Nordwesten, und einem Mischwald aus Tannen und Laubbäumen mit Hemlocktanne (Tsuga canadensis) im Süden und Südosten. Im Nordwesten hat die Tanne (Abies) die Kiefer in der Höhe ersetzt, und auf dem Hochland von New Brunswick wuchs ein nördlicher Wald. Um 6000 v.u.Z. war die dominierende Vegetation auf Prince Edward Island und in Nova Scotia ein Mischwald mit Tannen und Laubbäumen, wobei die Hemlocktanne dominierte. Die Insel Cape Breton war von einem Tannen-Laubbaum-Mischwald mit Kiefer und/oder Tanne bedeckt, mit Ausnahme des südlichen Teils der Insel, wo es wahrscheinlich Hemlocktannen gab. Die Analyse der Fossil-Plätze zeigt, daß eine warme trockene Periode die Vegetationszusammensetzung um 6000 Jahre $v$ u.Z. beeinflußte.

\footnotetext{
Manuscrit reçu le 16 septembre 1994; manuscrit révisé accepté le 7 novembre 1994

* Geological Survey of Canada contribution no. 42594
} 


\section{INTRODUCTION}

The Holocene history of New Brunswick has been documented in a number of regional studies (Auer, 1930; Korpijaakko, 1977; Osvald, 1970; Terasmae, 1973; Mott, 1975; Green, 1976; Walker and Paterson, 1983). With the exception of Basswood Road Lake (Mott, 1975), most of the sites in these studies are poorly dated and of limited use for the reconstruction of the vegetation and climate of New Brunswick $6000 \mathrm{yr}$ BP. This synthesis, in addition to compiling existing information for this time slice in $\mathrm{New}$ Brunswick, presents information on five new sites, including two long sequences, that were selected to fill geographical gaps in the data coverage for this province.

The Holocene history of Nova Scotia is better known (Auer, 1930; Livingstone and Livingstone, 1958; Ogden, 1960; Livingstone and Estes, 1967; Livingstone, 1968; Railton, 1972; Terasmae, 1973; Hadden, 1975; Green, 1976; Ogden, 1987; Jetté and Mott, 1989). However, because the late-glacial period has been the focus of most of the paleoecological studies in Nova Scotia (Ogden, 1980; Mott et al. (1986a); Mott et al. (1986b); Stea and Mott, 1988; Prinzen, 1990), often only the basal sections of the cores have been dated, resulting in a poorly controlled Holocene chronology. Five new sites, including one long sequence, are presented for this province, so that some specific questions such as, for example, the time of arrival and maximum representation of hemlock in Cape Breton Island can be resolved.

Prince Edward Island has been well documented by Anderson (1980, 1985) and by Frankel and Crowl (1961). The existing coverage is quite complete and no new sites are presented for this province. However, a new date has been added for the purpose of locating precisely the $6 \mathrm{ka}$ period in one of the existing sequences.

In order to interpret past changes in pollen diagrams, and to establish the relationship between different vegetation types and their pollen assemblages, surface samples were collected from a number of sites in the Maritime provinces. These and other surface samples from Maritime Canada are reported here for the first time.

A first difficulty encountered when preparing a synthesis arises from the need to extract information from a variety of studies which may differ appreciably in the methodology and data presentation. For example, in the absence of raw data, it is often difficult to correctly interpret older pollen diagrams since they generally lack key taxa or contain one or more groups of ecologically diverse taxa.

Because pollen sequences from lakes are rare, especially in New Brunswick, it has been necessary to use information from bogs in order to complement the regional framework. This presents a second difficulty because lakes and bogs are different depositional environments; peat deposits tend to reflect the local vegetation, while lakes, which record the regional pollen rain, are more representative of the vegetation on a regional scale.

A third difficulty resides in the fact that the pollen sequences often lack good chronological control. For exam- ple, for many of the dated sites presented by Korpijaakko (1977) and Terasmae (1973), only the base of the organics, above mineral sediment, has been dated. At some sites, it is reasonable to suspect that anomalous dates were obtained because of the hardwater effect that has been demonstrated many times in this area (Mott, 1975; Jetté and Mott, 1989; Jetté and Richard, 1992; Jetté and Mott, in prep.). Old carbonates derived from sedimentary rocks of Paleozoic, late Proterozoic and Mesozoic ages have been reworked by the glaciers and incorporated into till. In postglacial time, the leaching of the till carried the old carbonates into lakes where they were assimilated by microorganisms and incorporated into the organic sediment (Jetté and Mott, 1989). At Lac à Raymond, in southern Québec (Jetté and Richard, 1992), and Island Lake, in northern New Brunswick (Jetté and Mott, in prep.), discrepancies of 1850 and 2400 years respectively have been directly measured between dates on bulk sediment by conventional ${ }^{14} \mathrm{C}$ methods and dates on terrestrial remains by accelerator ${ }^{14} \mathrm{C}$ methods. At two other sites, Little Lake, southern New Brunswick (Mott, 1975) and Chance Harbour Lake, northern Nova Scotia (Jetté and Mott, 1989), the discrepancy has been demonstrated by comparison with the regional chronology as defined by well-controlled ${ }^{14} \mathrm{C}$ sites. At these two sites, discrepancies ranging from 500 to 3000 years were observed. The discrepancies provide a measure of "hardwater error" as a function of carbonate contamination.

Sometimes, when the source of contamination is the till, only the basal 2 to $3 \mathrm{~m}$ of the cores have been contaminated by leaching of the till during the Postglacial (Jetté and Mott, 1989). Other times, when the source of contamination, i.e. carbonate bedrock, is located near the study site, the whole sequence yields anomalous dates, such as is seen at Little Lake (Mott, 1975). Extra care has been taken in this synthesis to include and identify those sites demonstrating the hard-water effect.

\section{MODERN CONDITIONS}

\section{REGIONAL CLIMATE}

The climate of the three Maritime provinces, New Brunswick, Nova Scotia and Prince Edward Island, is described in the Atlantic Canada Climatic Region of Hare and Thomas (1974). The vegetation of the area has been classified by Rowe (1972) as the Acadian forest region which, before settlement, covered much of the Maritime provinces. Recently, the "Ecoregions Working Group" of Environment Canada (1989) has harmoniously merged climatic trends and vegetational coverage in "The Ecoclimatic Regions of Canada". This work has been extensively used as a reference document for this study.

The circulation of continental airmasses coming from the west causes wide fluctuations of temperature, resulting in a continental type of climate over the three Maritime provinces. However, the presence of the sea imposes a climatic control and has a strong influence over the four seasons. Spring is delayed along the northern coasts of the provinces, especially along Prince Edward Island, due to the 
presence of ice in the Gulf of St. Lawrence. Fog is common along the coasts and the summers are relatively short. This is explained by the presence of a strong temperature gradient between the warm interior and the relatively cool coastal areas where adjacent sea temperatures are relatively cold due to the influx of water from the Labrador current. As upland areas are warmer than coastal areas, the monthly isotherms are oriented parallel to the coast lines. The moderating effect of the Atlantic Ocean and the Gulf prolongs autumn and delays winter for a few weeks until nearly midDecember. Finally, fall and early winter are very wet seasons in Atlantic Canada as tropical hurricanes have a tendency to move up the east coast towards the Atlantic provinces (Hare and Thomas, 1974).

\section{TOPOGRAPHY, TEMPERATURE AND PRECIPITATION}

\section{New Brunswick}

New Brunswick has a distinct topography. In the northwest, the northern highlands exceed elevations of $600 \mathrm{~m}$ a.s.l. whereas near Fundy Bay, the southern highlands do not reach the 600 metre level. The rest of the province is characterized by low elevations (0 to $151 \mathrm{~m}$ ) (Fig. 1).

The coldest mean July temperature (less than $18^{\circ} \mathrm{C}$ ) is recorded on the northern highlands (Fig. 2) and on the south shore of the province. The central part of the province records the warmest mean July value for Atlantic Canada $\left(19^{\circ} \mathrm{C}\right)$. The mean annual precipitation isohyets (Fig. 3) range from $670 \mathrm{~mm}$ on the northern highlands to $1219 \mathrm{~mm}$ in the southern part of the province.

\section{Nova Scotia}

The topography of mainland Nova Scotia is characterized by low hills and plateaus. With the exception of the northern regions, most of the highlands do not exceed $300 \mathrm{~m}$ a.s.l. The highlands of Cape Breton Island are characterized by elevations greater than 300 metres. The rest of the province is part of the Maritime lowlands.

Central Nova Scotia and Cape Breton Island record a mean July temperature of $18^{\circ} \mathrm{C}$ with temperatures less than $17^{\circ} \mathrm{C}$ along the coast. Annual precipitation ranges from $1016 \mathrm{~mm} /$ year for the northern parts of Nova Scotia and Cape Breton Island and more than $1422 \mathrm{~mm} / \mathrm{yr}$ for southern Nova Scotia.

\section{Prince Edward Island}

Prince Edward Island has much of its surface undulating at elevations of less than $60 \mathrm{~m}$ above sea level. Elevations do not exceed $151 \mathrm{~m}$ a.s.I. Mean July temperature is $19^{\circ} \mathrm{C}$ and annual precipitation ranges between 914 and 1016 $\mathrm{mm} / \mathrm{yr}$.

\section{VEGETATION AND CLIMATE}

The vegetation (Fig. 4) reflects the topography and the climate. According to Environment Canada (1989) the Maritime provinces are characterized by two distinct ecoclimatic provinces: the Cool Temperate Province and the Boreal Province. The Cool Temperate Province occupies Prince Edward Island, central Nova Scotia and most of New Brunswick with the exception of the coastal area around Bay of
FIGURE 1. Topography and location map. Source: Energy, Mines and Resources Canada Geographical Map Series no. 11976).

Localisation et topographie des provinces maritimes. Source: Énergie, Mines et Ressources Canada, carte géographique $n^{\circ} 1$ 1976).

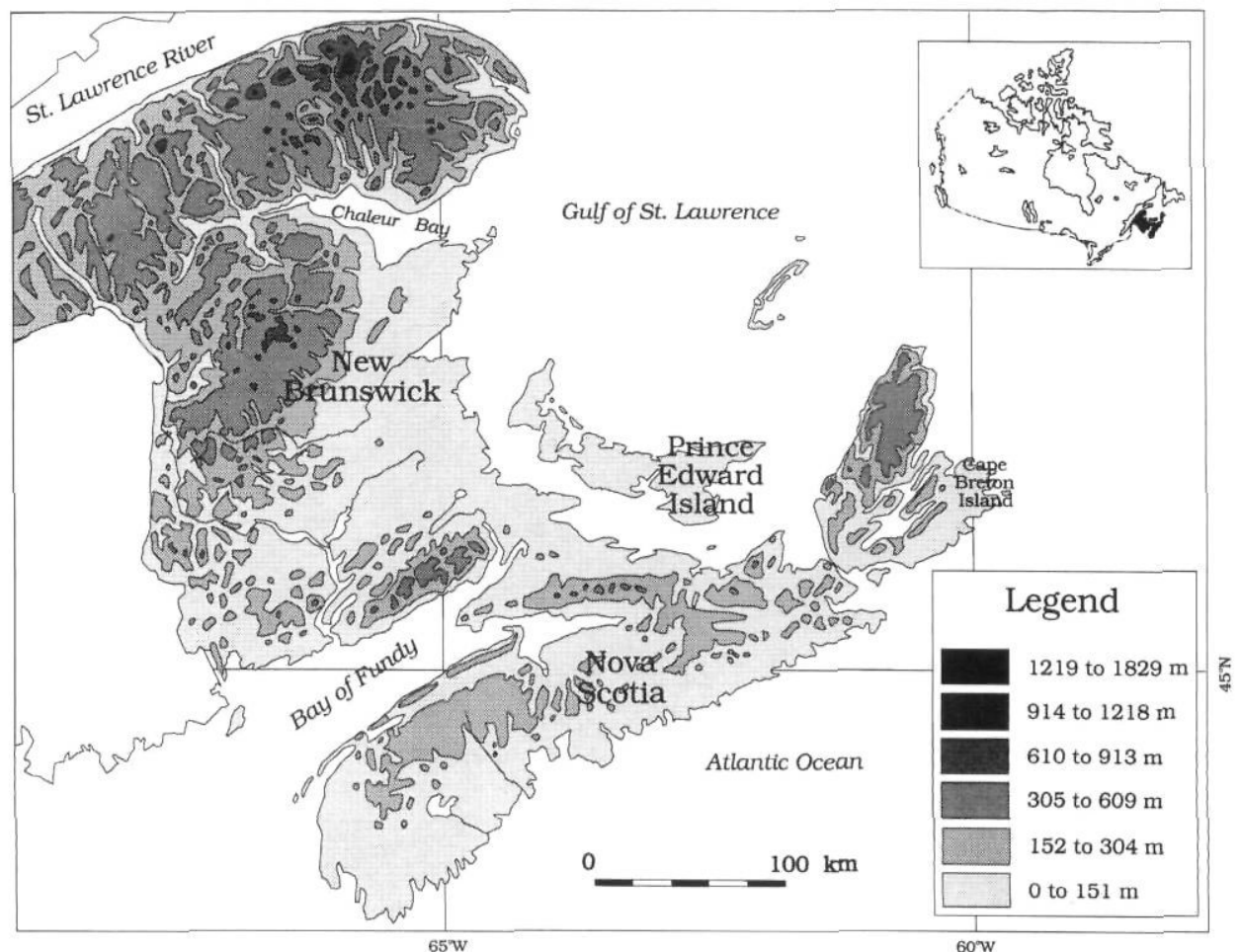

Géographie physique et Quaternaire, 49(1), 1995 

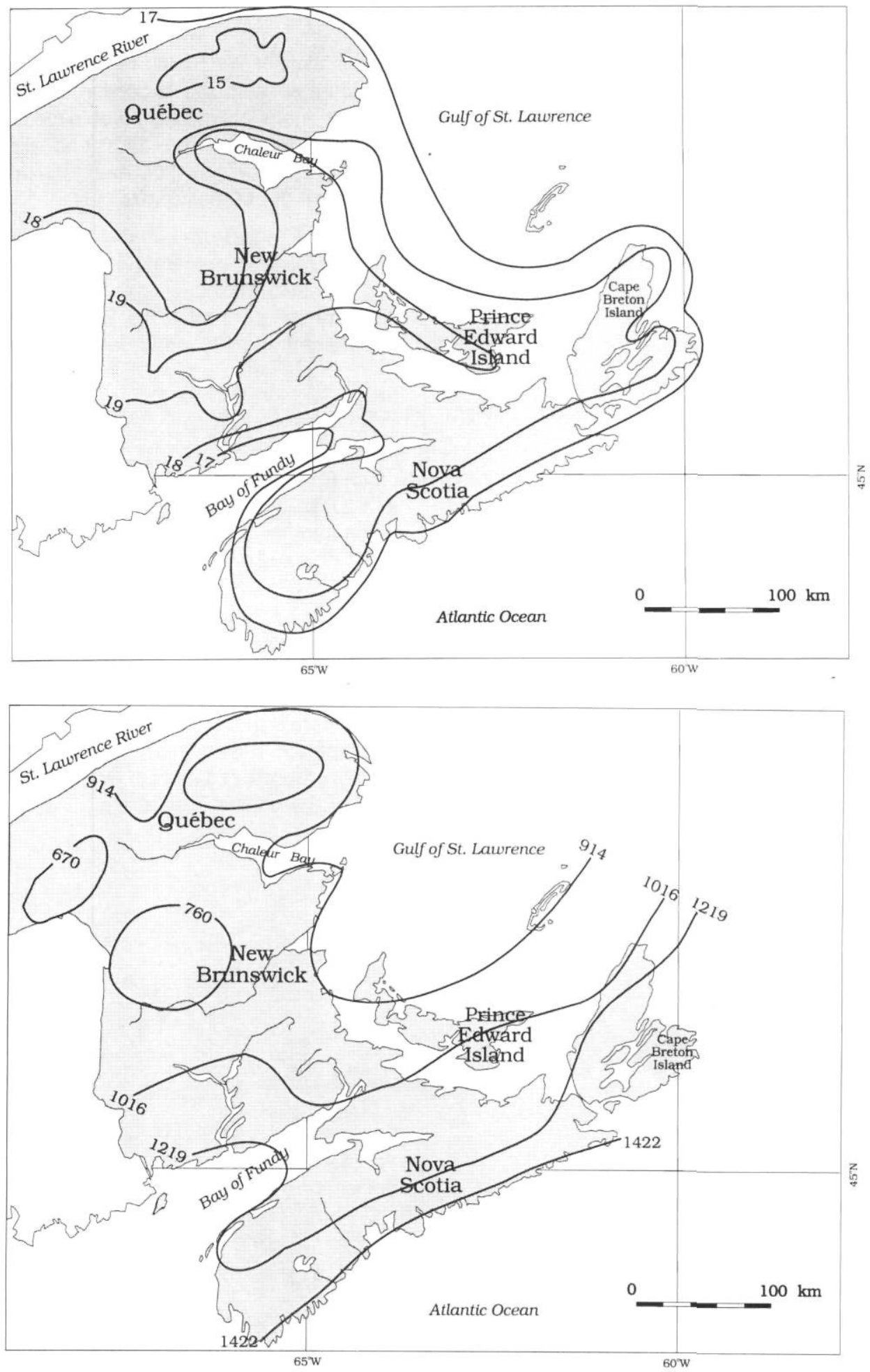

FIGURE 2. Mean July temperature isotherms for Maritime Canada. Source: Anderson (1985).

Isothermes des températures moyennes de juillet dans les provinces maritimes. Source : Anderson (1985).

FIGURE 3. Annual precipitation for Maritime Canada. Source: Anderson (1985).

Isohyètes annuelles des provinces maritimes. Source: Anderson (1985).
Fundy. The boreal province occupies Cape Breton Island and coastal zones around Nova Scotia and southern New Brunswick. The ecoclimatic provinces are further divided into ecoclimatic regions.

\section{The Cool Temperate Province}

Transitional High Cool temperate Zone (HCTt): mixed forests of sugar maple (Acer saccharum), beech (Fagus grandifolia) and yellow birch (Betula alleghaniensis) occupy ridges while eastern hemlock (Tsuga canadensis), balsam fir (Abies balsamea), eastern white pine (Pinus strobus) and white spruce (Picea glauca) are present in the valleys. Stands with a fire origin are characterized by trembling aspen (Populus tremuloides) while black spruce (Picea mariana) and eastern white cedar (Thuja occidentalis) are associated with wetlands. Summers are warm and moist 
FIGURE 4. Ecoclimatic provinces and regions for Maritime Canada. Source: Ecological Land Classification Series, No. 23, Environment Canada (1989).

Provinces et régions écoclimatiques des provinces maritimes. Source : Classification écologiques des terres, $n^{\circ} 23$, Environnement Canada (1989).

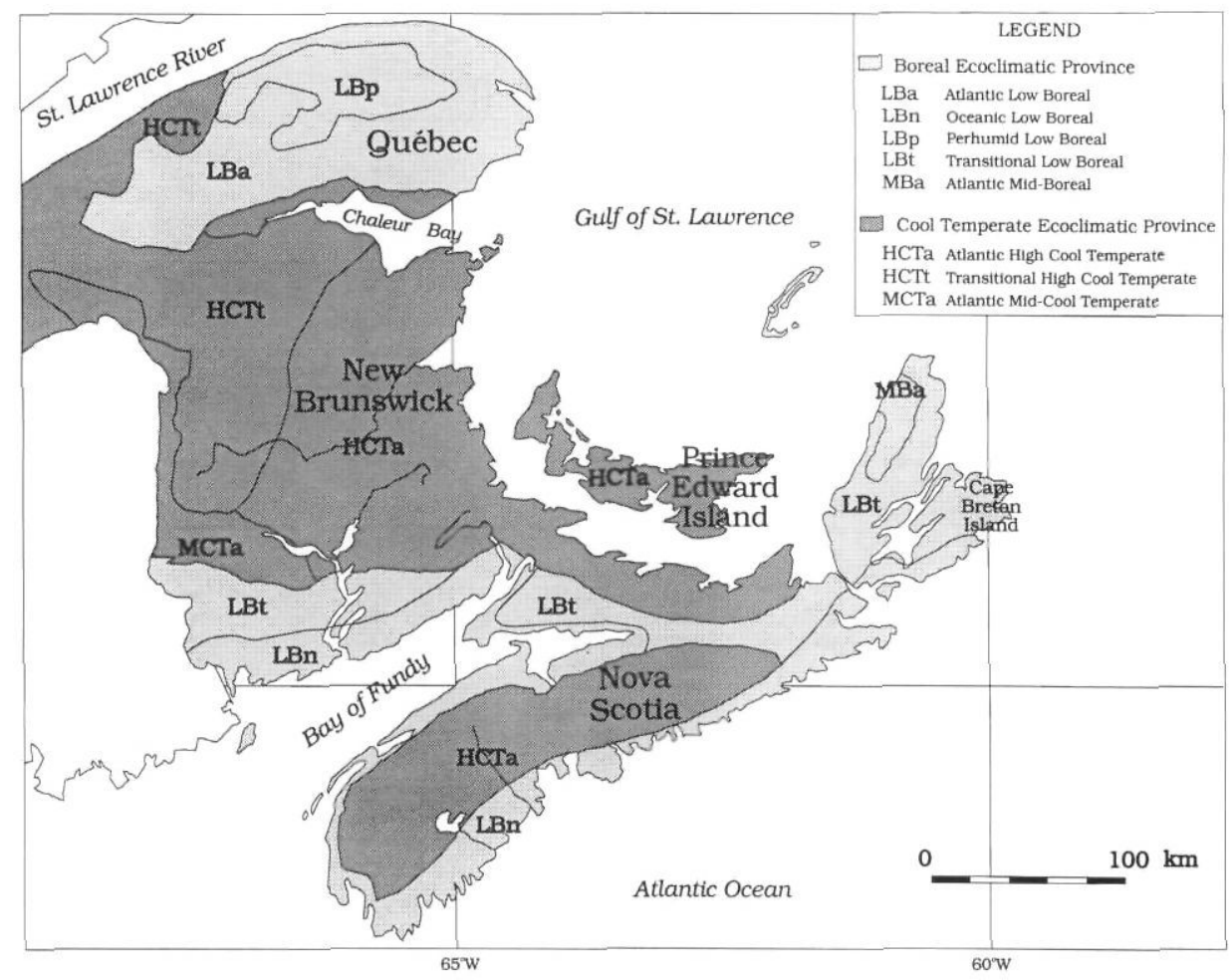

while winters are cold. The frost-free period lasts approximately 70 to 80 days.

Atlantic High Cool Temperate Zone (HCTa): mixed forests of red spruce (Picea rubens), eastern white pine, red oak (Quercus rubra), and red maple (Acer rubrum) occupy well-drained sites. Poorly drained sites support stands of black spruce and balsam fir. Bogs occupy large portions of this ecoregion, particularly in eastern New Brunswick. Summers are warm and winters are mild and snowy. The frostfree period lasts between 110 and 140 days.

Atlantic Mid-Cool Temperate Zone (MCTa): hardwood forests composed of sugar maple, yellow birch, and beech predominate, with minor occurrences of white ash (Fraxinus americana), butternut (Juglans cinerea), ironwood (Ostrya virginiana) and basswood (Tilia americana). Black ash (Fraxinus nigra) occupies poorly drained terrain whereas red spruce, red maple, balsam fir, and eastern hemlock are on the better drained sites. Summers are warm and moist while winters are mild to cold and snowy. The frost-free period lasts approximately 120 days.

\section{The Boreal Province}

Transitional Low Boreal Zone (LBt): mixed forests of sugar maple, yellow birch, red maple, white spruce, red spruce and balsam fir characterize this ecoregion. Sugar maple and beech occupy warmer and moister sites. Eastern white pine dominates drier terrain. Black spruce, tamarack (Larix laricina) and eastern white cedar (mainly on the calcareous soils of New Brunswick), black ash and red maple occupy areas of poor drainage. Summers are warm and rainy and winters are mild and snowy.
Oceanic Low Boreal Zone (LBn): Coniferous forests dominated by balsam fir, white spruce and black spruce characterize this ecoregion. White spruce dominates exposed areas along the coast but red spruce is generally absent. Red maple, paper birch (Betula papyrifera), and yellow birch are also present. In areas of poor drainage, Sphagnum bogs are common. Summers are warm and rainy and winters are mild and wet. Fog is a frequent feature. Temperatures greater than $0^{\circ} \mathrm{C}$ extend from mid-March to early December (271 days) with winter temperatures seldom averaging below $-4^{\circ} \mathrm{C}$. There is a strong and direct influence from the Atlantic Ocean and Bay of Fundy.

Atlantic Mid-Boreal Zone (MBa): Forests of black spruce and/or balsam fir and an understorey of feathermoss characterize this ecoregion. Low-growing heath communities, typified by Kalmia and moss, occupy areas repeatedly struck by fire. In poorly drained localities, Kalmia heath dominates open stands of black spruce and tamarack with an understorey of Sphagnum. Alder (Alnus) is present in areas of poor drainage. Summers are cool and winters are mild. Spring conditions are severely influenced by ice flows from the north, which shorten the growing season.

\section{MODERN POLLEN-VEGETATION RELATIONSHIP}

Modern pollen assemblages from five of the six ecoclimatic zones are presented (Fig. 5) in order to illustrate the link between pollen rain and modern vegetation. Unfortunately, no data was available from the MBa zone. For large areas of the Maritime Provinces, the vegetation has been greatly disturbed. In Prince Edward Island, in areas historically covered by hardwoods such as red oak, beech and sugar maple, abandoned fields are reverting to 


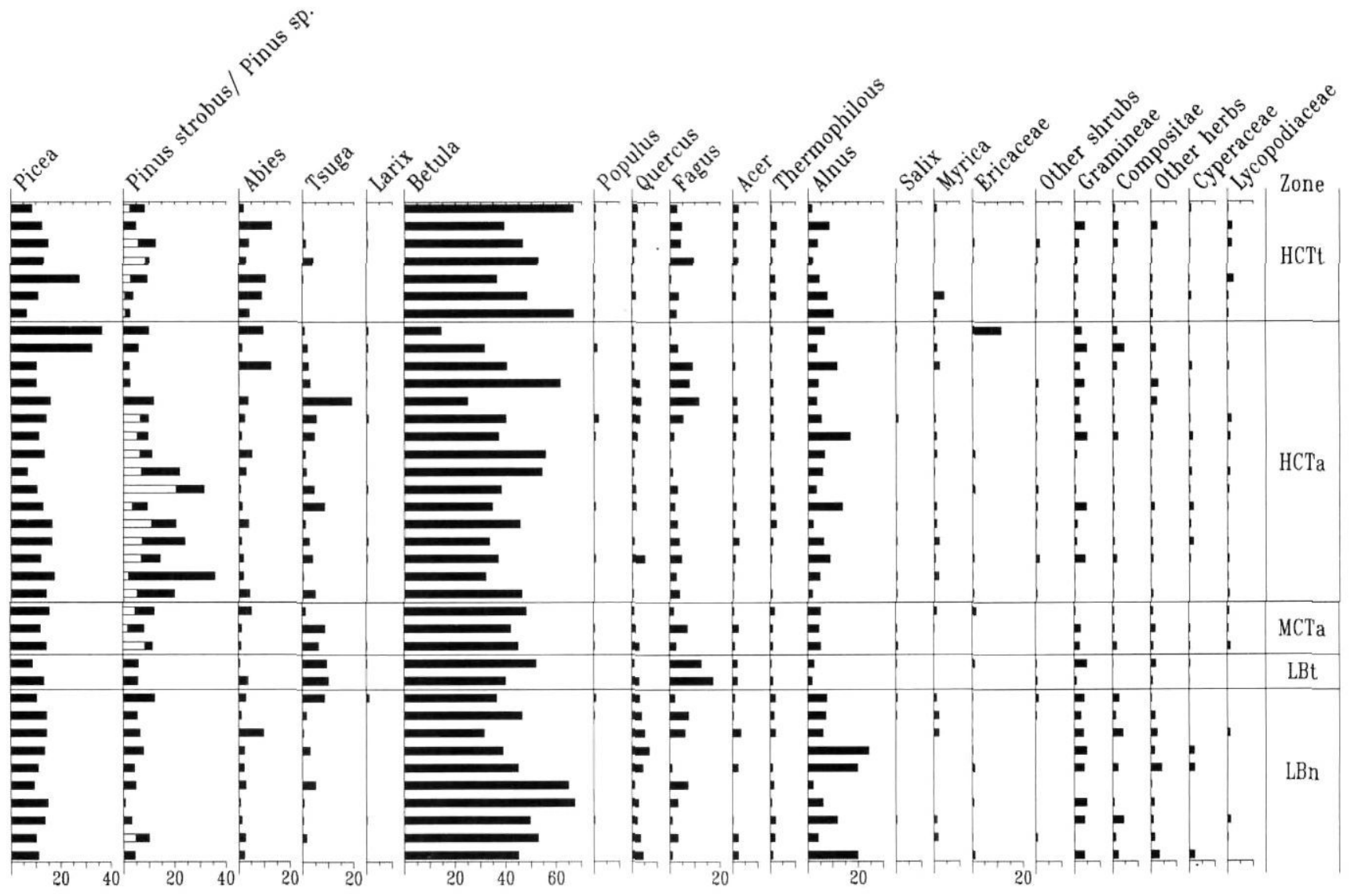

FIGURE 5. Surface samples from Maritime Canada, grouped by ecoclimatic regions.

forests of white and red spruce, a common transition stage throughout the Maritimes (Environment Canada, 1989). Fire has also played a role in southwestern Nova Scotia and, as a result, much of the terrain in this area is covered by low shrubs (Environment Canada, 1989). For this reason, in order to demonstrate the link between climate and vegetation, the sites where human disturbance could be identified (high percentages of ragweed (Ambrosia), grasses, Artemisia or sorrel (Rumex)) have been eliminated in this review. Most of the sites show some indication of disturbance. Only surface samples from lakes are presented in order to document the regional vegetation surrounding the survey sites.

Environment Canada (1989) places the LBt and LBn zones in the boreal forest type. However, according to Rowe (1972), since some deciduous species such as maple and beech are present in the landscape, these forest types would qualify as the Acadian forest, which is a mixed deciduous-coniferous forest. Rowe (1972) also suggests that the boreal forest in the Maritime Provinces is restricted to high elevations, more than $450 \mathrm{~m}$, in New Brunswick, and more than $330 \mathrm{~m}$ on Cape Breton Island, and to a thin border along the sea corresponding roughly to the $17.5^{\circ} \mathrm{C}$ mean July isotherm around Bay of Fundy and to the $17^{\circ} \mathrm{C}$ mean July isotherm on the south shore of Nova Scotia.

The pollen spectra are in agreement with Rowe, most of them recording maple, beech and other thermophilous spe-
Échantillons de surface regroupés par région écoclimatique des provinces maritimes.

cies, in addition to conifers. Spruce (Picea) is not dominant, except locally in peatbogs. Birch (Betula) is present throughout the Maritimes with percentages reaching $60 \%$ at some locations and beech (Fagus) can be well represented locally. Hemlock (Tsuga) representation rarely exceeds $10 \%$ and pine (Pinus) is not too abundant, rarely more than $30 \%$. According to Rowe (1972), large and almost pure stands of eastern hemlock were present and white pine was abundant, until recently, in the southern part of the HCTa zone in Nova Scotia; unfortunately the surface samples from this area are not representative of these pre-settlement forests.

The forest zones are characterized by the following coniferous species: HCTt and LBn by fir (Abies), HCTa by pine, including white pine (Pinus strobus), and MCTa and LBt by hemlock (Tsuga). Our reconstruction of the past vegetation will be based on these observations.

These forest zones are linked to climate. The annual precipitation, mean July, mean January temperatures and degree/day values for meteorological stations located in the middle of the ecoclimatic zones are presented on Table I. HCTt and LBn, both characterized by fir, have a similar mean July temperature $\left(17^{\circ} \mathrm{C}\right)$. Total precipitation and mean January temperature are higher for LBn, in direct maritime location, as opposed to HCTt, located mostly on the New Brunswick plateau. HCTa, characterized by white pine, has a warmer mean July temperature $\left(18.5^{\circ} \mathrm{C}\right)$ than the two 
TABLE I

Meteorological data according to ecoclimatic zones

\begin{tabular}{|c|c|c|c|c|}
\hline Ecoclimatic zone & $\begin{array}{l}\text { Mean January } \\
\text { temperature }\end{array}$ & $\begin{array}{l}\text { Mean July } \\
\text { temperature }\end{array}$ & $\begin{array}{l}\text { Degree } \\
\text {-days }\end{array}$ & Total precipitation \\
\hline HCTt (6 st.) & -12.8 & 16.8 & - & 1033 \\
\hline LBn (14 st.) & -5.25 & 16.9 & 1573 & 1272 \\
\hline HCTa (18 st.) & -7.7 & 18.5 & 1683 & 1243 \\
\hline MCTa (9 st.) & -10.1 & 19.1 & 1719 & 1082 \\
\hline LBt (7 st.) & -7.7 & 19 & 1725 & 1231 \\
\hline
\end{tabular}

(st.: number of meteorological stations used for the compilation).

TABLE ॥

Pollen sites from Maritime Canada and southern Québec

\begin{tabular}{|c|c|c|c|c|}
\hline & Name & Coord. & Dates & References \\
\hline 1) Lac Caribou* & $\begin{array}{l}48^{\circ} 12^{\prime} \mathrm{N} \\
64^{\circ} 56^{\prime} \mathrm{W}\end{array}$ & $\begin{array}{l}2600 \pm 110 \\
6100 \pm 170 \\
8850 \pm 260\end{array}$ & $\begin{array}{r}4010 \pm 110 \\
8250 \pm 110 \\
10000 \pm 400\end{array}$ & Jetté and Richard, 1992 \\
\hline 2) Lac à Robin & $\begin{array}{l}48^{\circ} 03^{\prime} \mathrm{N} \\
65^{\circ} 16^{\prime} \mathrm{W}\end{array}$ & $\begin{array}{l}3310 \pm 080 \\
7500 \pm 110\end{array}$ & $\begin{array}{l}5300 \pm 080 \\
9800 \pm 080\end{array}$ & Jetté and Richard, 1992 \\
\hline 3) Lac à Raymond* & $\begin{array}{l}48^{\circ} 14^{\prime} \mathrm{N} \\
65^{\circ} 51^{\prime} \mathrm{W}\end{array}$ & $\begin{array}{r}3140 \pm 100 \\
10150 \pm 220\end{array}$ & $\begin{aligned} 5990 & \pm 060 \\
12000 & \pm 240^{\star}\end{aligned}$ & Jetté and Richard, 1992 \\
\hline 4) Island Lake* & $\begin{array}{l}47^{\circ} 49^{\prime} \mathrm{N} \\
66^{\circ} 11^{\prime} \mathrm{W}\end{array}$ & $\begin{array}{l}5940 \pm 110 \\
9920 \pm 060\end{array}$ & $\begin{array}{r}8650 \pm 100 \\
12300^{*} \pm 210\end{array}$ & Jetté et al., in prep. \\
\hline 5) Tracadie Bog & $\begin{array}{l}47^{\circ} 28^{\prime} \mathrm{N} \\
65^{\circ} \mathrm{W}\end{array}$ & $8044 \pm 071$ & & Korpijaakko, 1977 \\
\hline 6) Escuminac Bog & $\begin{array}{l}46^{\circ} 55^{\prime} \mathrm{N} \\
65^{\circ} 06^{\prime} \mathrm{W}\end{array}$ & & & Auer, 1930 \\
\hline 7) Shaddick Lake* & $\begin{array}{l}47^{\circ} 05^{\prime} \mathrm{N} \\
65^{\circ} 51^{\prime} \mathrm{W}\end{array}$ & $6460 \pm 130$ & $10100 \pm 170$ & This paper \\
\hline 8) St.Quentin Bog & $\begin{array}{l}47^{\circ} 28^{\prime} \mathrm{N} \\
67^{\circ} 28^{\prime} \mathrm{W}\end{array}$ & $10664 \pm 77$ & & Korpijaakko, 1977 \\
\hline 9) Grand Falls* & $\begin{array}{l}47^{\circ} 30^{\prime} \mathrm{N} \\
67^{\circ} 44^{\prime} \mathrm{W}\end{array}$ & $9830 \pm 160$ & & Terasmae, 1973 \\
\hline 10) Route 17 Bog & $\begin{array}{l}47^{\circ} 20^{\prime} \mathrm{N} \\
67^{\circ} 40^{\prime} \mathrm{W}\end{array}$ & & & Korpijaakko, 1977 \\
\hline 11) Roulston Lake* & $\begin{array}{l}46^{\circ} 53^{\prime} \mathrm{N} \\
67^{\circ} 24^{\prime} \mathrm{W}\end{array}$ & $\begin{array}{l}5480 \pm 150 \\
9930 \pm 160\end{array}$ & $\begin{array}{r}8150 \pm 130 \\
11100 \pm 90\end{array}$ & $\begin{array}{l}\text { Mott et al., 1986; } \\
\text { this paper }\end{array}$ \\
\hline 12) Hartland Bog & $\begin{array}{l}46^{\circ} 36^{\prime} \mathrm{N} \\
67^{\circ} 39^{\prime} \mathrm{W}\end{array}$ & $7860 \pm 070$ & & Terasmae, 1973 \\
\hline 13) Woodstock Bog & $\begin{array}{l}46^{\circ} 10^{\prime} \mathrm{N} \\
67^{\circ} 29^{\prime} \mathrm{W}\end{array}$ & & & Korpijaakko, 1977 \\
\hline 14) Timber Pond Bog & $\begin{array}{l}46^{\circ} 30^{\prime} \mathrm{N} \\
66^{\circ} 20^{\prime} \mathrm{W}\end{array}$ & & & Korpijaakko, 1977 \\
\hline 15) Birch Ridges Bog & $\begin{array}{l}46^{\circ} 30^{\prime} \mathrm{N} \\
66^{\circ} 20^{\prime} \mathrm{W}\end{array}$ & & & Korpijaakko, 1977 \\
\hline 16) Bull Pasture Bog & $\begin{array}{l}46^{\circ} 02^{\prime} \mathrm{N} \\
60^{\circ} 20^{\prime} \mathrm{W}\end{array}$ & $8160 \pm 076$ & & Korpijaakko, 1977 \\
\hline 17) Fredericton Bog & $\begin{array}{l}45^{\circ} 56^{\prime} \mathrm{N} \\
66^{\circ} 41^{\prime} \mathrm{W}\end{array}$ & & & Mott, 1975 \\
\hline 18) North Renous Bog & $\begin{array}{l}42^{\circ} 52^{\prime} \mathrm{N} \\
66^{\circ} 37^{\prime} \mathrm{W}\end{array}$ & $6640 \pm 065$ & & Korpijaakko, 1977 \\
\hline
\end{tabular}




\begin{tabular}{|c|c|c|c|c|}
\hline & Name & Coord. & Dates & References \\
\hline 19) Regent Street Bog & $\begin{array}{l}45^{\circ} 55^{\prime} \mathrm{N} \\
66^{\circ} 40^{\prime} \mathrm{W}\end{array}$ & $8684 \pm 087$ & & Korpijaakko, 1977 \\
\hline 20) Bacon Lake* & $\begin{array}{l}45^{\circ} 32^{\prime} \mathrm{N} \\
66^{\circ} 27^{\prime} \mathrm{W}\end{array}$ & $\begin{array}{r}5120 \pm 140 \\
11300 \pm 240\end{array}$ & $\begin{array}{r}8890 \pm 150 \\
13700 \pm 210\end{array}$ & This paper \\
\hline 21) Basswood Road L.* & $\begin{array}{l}45^{\circ} 15^{\prime} \mathrm{N} \\
67^{\circ} 20^{\prime} \mathrm{W}\end{array}$ & $\begin{array}{r}3020 \pm 150 \\
6530 \pm 210 \\
11300 \pm 180\end{array}$ & $\begin{aligned} 5120 & \pm 220 \\
9460 & \pm 200 \\
12600 & \pm 270\end{aligned}$ & Mott, 1975 \\
\hline 22) St.Andrews Bog & $\begin{array}{l}45^{\circ} 10^{\prime} \mathrm{N} \\
66^{\circ} 40^{\prime} \mathrm{W}\end{array}$ & $7222 \pm 067$ & & Korpijaakko, 1977 \\
\hline 23) Little Lake & $\begin{array}{l}45^{\circ} 08^{\prime} \mathrm{N} \\
66^{\circ} 43^{\prime} \mathrm{W}\end{array}$ & $\begin{array}{r}6440 \pm 300 \\
14300^{*} \pm 220\end{array}$ & $\begin{array}{r}9140 \pm 230 \\
16500^{*} \pm 370\end{array}$ & Mott, 1975 \\
\hline 24) Spruce Lake Bog & $\begin{array}{l}45^{\circ} 20^{\prime} \mathrm{N} \\
65^{\circ} 45^{\prime} \mathrm{W}\end{array}$ & & & Osvald, 1970 \\
\hline 25) Portey Pond & $\begin{array}{l}45^{\circ} 51^{\prime} \mathrm{N} \\
64^{\circ} 25^{\prime} \mathrm{W}\end{array}$ & & & Walker and Paterson, 1983 \\
\hline 26) Wood's Pond & $\begin{array}{l}45^{\circ} 53^{\prime} \mathrm{N} \\
64^{\circ} 24^{\prime} \mathrm{W}\end{array}$ & $9930 \pm 350$ & & Walker and Paterson, 1983 \\
\hline 27) Collins Lake & $\begin{array}{l}46^{\circ} 06^{\prime} \mathrm{N} \\
64^{\circ} 06^{\prime} \mathrm{W}\end{array}$ & $\begin{array}{r}910 \pm 090 \\
5500 \pm 170\end{array}$ & $\begin{array}{l}2175 \pm 200 \\
5450 \pm 200\end{array}$ & Green, 1976 \\
\hline 28) Poucette Lake* & $\begin{array}{l}46^{\circ} 03^{\prime} \mathrm{N} \\
64^{\circ} 17^{\prime} \mathrm{W}\end{array}$ & $\begin{aligned} 5540 & \pm 120 \\
10500 & \pm 170\end{aligned}$ & $9560 \pm 120$ & This paper \\
\hline 29) Wigmore Lake* & $\begin{array}{l}45^{\circ} 44^{\prime} \mathrm{N} \\
63^{\circ} 38^{\prime} \mathrm{W}\end{array}$ & $\begin{array}{r}6590 \pm 170 \\
11400 \pm 140\end{array}$ & & This paper \\
\hline 30) Folly Bog & $\begin{array}{l}45^{\circ} 33^{\prime} \mathrm{N} \\
63^{\circ} 33^{\prime} \mathrm{W}\end{array}$ & $10764 \pm 101$ & & Livingstone, 1968 \\
\hline 31) Chance Harbour L.* & $\begin{array}{l}45^{\circ} 40^{\prime} \mathrm{N} \\
62^{\circ} 37^{\prime} \mathrm{W} \\
45^{\circ} 31^{\prime} \mathrm{N} \\
62^{\circ} 12^{\prime} \mathrm{W}\end{array}$ & $\begin{aligned} 2920 & \pm 090 \\
6540 & \pm 120 \\
9220 & \pm 090 \\
12100^{*} & \pm 120 \\
5690 & \pm 150\end{aligned}$ & $\begin{array}{r}4850 \pm 070 \\
7050 \pm 100 \\
11300^{*} \pm 190 \\
13400^{*} \pm 160\end{array}$ & $\begin{array}{l}\text { Jetté and Mott, 1989; } \\
\text { this paper }\end{array}$ \\
\hline 33) Pye Lake* & $\begin{array}{l}45^{\circ} 05^{\prime} \mathrm{N} \\
62^{\circ} 00^{\prime} \mathrm{W}\end{array}$ & $\begin{aligned} 1140 & \pm 080 \\
6000 & \pm 060 \\
10000 & \pm 160 \\
12200 & \pm 220\end{aligned}$ & $\begin{aligned} 4440 & \pm 090 \\
8120 & \pm 140 \\
10800 & \pm 190\end{aligned}$ & This paper \\
\hline 34) Shaw's Bog & $\begin{array}{l}45^{\circ} 01^{\prime} \mathrm{N} \\
64^{\circ} 11^{\prime} \mathrm{W}\end{array}$ & $\begin{array}{l}4415 \pm 130 \\
8505 \pm 160\end{array}$ & $\begin{array}{l}6290 \pm 140 \\
9180 \pm 255\end{array}$ & Hadden, 1975 \\
\hline 35) Silver Lake & $\begin{array}{l}44^{\circ} 33^{\prime} \mathrm{N} \\
63^{\circ} 38^{\prime} \mathrm{W}\end{array}$ & $\begin{array}{l}4540 \pm 140 \\
9650 \pm 150\end{array}$ & $7140 \pm 140$ & Ogden, 1987 \\
\hline 36) Penhorn Lake & $\begin{array}{l}44^{\circ} 41^{\prime} \mathrm{N} \\
63^{\circ} 33^{\prime} \mathrm{W}\end{array}$ & $9035 \pm 350$ & $11730 \pm 440$ & Ogden, 1987 \\
\hline 37) Caribou Bog & $\begin{array}{l}45^{\circ} 02^{\prime} \mathrm{N} \\
64^{\circ} \mathrm{W}\end{array}$ & & & Auer, 1930; Ogden, 1960 \\
\hline 38) Canoran Lake & $\begin{array}{l}44^{\circ} 36^{\prime} \mathrm{N} \\
64^{\circ} 34^{\prime} \mathrm{W}\end{array}$ & $11700 \pm 160$ & & Railton, 1972 \\
\hline 39) Minard Lake & $\begin{array}{l}44^{\circ} 30^{\prime} \mathrm{N} \\
64^{\circ} 25^{\prime} \mathrm{W}\end{array}$ & $\begin{aligned} 108 & \pm 4.3 \\
2980 & \pm 260\end{aligned}$ & $\begin{array}{l}2370 \pm 165 \\
5735 \pm 220\end{array}$ & Railton, 1972 \\
\hline 40) Oak Hill Lake & $\begin{array}{l}44^{\circ} 23^{\prime} \mathrm{N} \\
64^{\circ} 34^{\prime} \mathrm{W}\end{array}$ & $\begin{array}{l}1005 \pm 135 \\
6230 \pm 235\end{array}$ & $\begin{array}{l}4905 \pm 225 \\
8250 \pm 365\end{array}$ & Railton, 1972 \\
\hline 41) Everitt Lake & $\begin{array}{l}44^{\circ} 27^{\prime} \mathrm{N} \\
65^{\circ} 52^{\prime} \mathrm{W}\end{array}$ & $\begin{array}{l}1070 \pm 200 \\
7030 \pm 340\end{array}$ & $\begin{array}{l}1940 \pm 180 \\
8080 \pm 410\end{array}$ & Green, 1976 \\
\hline 42) Bower Lake* & $\begin{array}{l}44^{\circ} 05^{\prime} \mathrm{N} \\
56^{\circ} 47^{\prime} \mathrm{W}\end{array}$ & $5930 \pm 110$ & & This paper \\
\hline
\end{tabular}




\begin{tabular}{|c|c|c|c|c|}
\hline & Name & Coord. & Dates & References \\
\hline 43) Curry Pond & $\begin{array}{l}43^{\circ} 53^{\prime} \mathrm{N} \\
65^{\circ} 51^{\prime} \mathrm{W}\end{array}$ & $8130 \pm 400$ & & Green, 1976 \\
\hline 44) Wreck Cove Lake & $\begin{array}{l}46^{\circ} 32^{\prime} \mathrm{N} \\
60^{\circ} 26^{\prime} \mathrm{W}\end{array}$ & $9030 \pm 170$ & & Livingstone and Estes, 1967 \\
\hline 45) Timber Lake* & $\begin{array}{l}46^{\circ} 23^{\prime} \mathrm{N} \\
60^{\circ} 40^{\prime} \mathrm{W}\end{array}$ & $5340 \pm 130$ & & This paper \\
\hline 46) McDougal Lake & $\begin{array}{l}46^{\circ} 00^{\prime} \mathrm{N} \\
60^{\circ} 30^{\prime} \mathrm{W}\end{array}$ & & & Lifingstone and Livingstone, 1958 \\
\hline 47) Port Hood Island & $\begin{array}{l}46^{\circ} 00^{\prime} \mathrm{N} \\
61^{\circ} 34^{\prime} \mathrm{W}\end{array}$ & $7140 \pm 140$ & & Livingstone, 1968 \\
\hline 48) Salmon River L. & $\begin{array}{l}45^{\circ} 38^{\prime} \mathrm{N} \\
60^{\circ} 46^{\prime} \mathrm{W}\end{array}$ & $5540 \pm 140$ & $8770 \pm 150$ & Livingstone and Livingstone, 1958 \\
\hline 49) Gillis Lake & $\begin{array}{l}45^{\circ} 39^{\prime} \mathrm{N} \\
60^{\circ} 46^{\prime} \mathrm{W}\end{array}$ & $10340 \pm 220$ & & Anderson, 1980 \\
\hline 50) Portage Bog & $\begin{array}{l}46^{\circ} 40^{\prime} \mathrm{N} \\
64^{\circ} 04^{\prime} \mathrm{W}\end{array}$ & $490 \pm 060$ & $3430 \pm 070$ & Anderson, 1980 \\
\hline 51) East Bideford & $\begin{array}{l}46^{\circ} 38^{\prime} \mathrm{N} \\
63^{\circ} 54^{\prime} \mathrm{N}\end{array}$ & $\begin{array}{r}390 \pm 080 \\
1960 \pm 120 \\
8070 \pm 080\end{array}$ & $\begin{array}{l}1130 \pm 080 \\
2140 \pm 060\end{array}$ & Anderson, 1980 \\
\hline 52) Mermaid Lake & $\begin{array}{l}46^{\circ} 15^{\prime} \mathrm{N} \\
63^{\circ} 01^{\prime} \mathrm{W}\end{array}$ & $8630 \pm 180$ & & Anderson, 1985 \\
\hline 53) MacLaughlin Pd. & $\begin{array}{l}46^{\circ} 22^{\prime} \mathrm{N} \\
62^{\circ} 50^{\prime} \mathrm{W}\end{array}$ & $\begin{array}{l}2080 \pm 130 \\
5060 \pm 090 \\
8050 \pm 100\end{array}$ & $\begin{array}{l}3660 \pm 080 \\
6350 \pm 080 \\
9670 \pm 130\end{array}$ & Anderson, per. comm. \\
\hline 54) East Baltic Bog & $\begin{array}{l}46^{\circ} 24^{\prime} \mathrm{N} \\
62^{\circ} 09^{\prime} \mathrm{W}\end{array}$ & $4020 \pm 060$ & $7000 \pm 070$ & Anderson, 1980 \\
\hline 55) Iris Station Bog & $\begin{array}{l}45^{\circ} 56^{\prime} \mathrm{N} \\
62^{\circ} 39^{\prime} \mathrm{W}\end{array}$ & $6600 \pm 270$ & & Frankel and Crowl, 1961 \\
\hline
\end{tabular}

The numbers on the Table correspond to the numbers on the location map. The sites for which a pollen diagram is presented are marked with an asterix. Date with an asterix have been deemed anomalous by the authors.

previous zones and MCTa and LBt, supporting hemlock, have the warmest mean July temperature $\left(19^{\circ} \mathrm{C}\right)$.

All the zones have quite high total precipitations values, from 1000 to $1300 \mathrm{~mm} / \mathrm{yr}$, due to the maritime influence. The three indicator species: fir, white pine and hemlock represent different ranges of temperature: fir growing best in areas characterized by a mean July temperature between $10^{\circ}$ and $21^{\circ} \mathrm{C}$, white pine by a mean July temperature between $17^{\circ}$ and $22^{\circ} \mathrm{C}$, and hemlock by a mean July temperature between $16^{\circ}$ and $25^{\circ} \mathrm{C}$ (Fowells, 1965). This is supported by a modern distribution range of fir located between latitudes $42^{\circ}$ and $57^{\circ} \mathrm{N}$, white pine between latitudes $34^{\circ}$ and $51^{\circ} \mathrm{N}$ and hemlock between latitudes $34^{\circ}$ and $48^{\circ} \mathrm{N}$ (Fowells, 1965).

\section{METHODOLOGY}

Ten new sites, including three complete sequences and seven short sequences bracketing the $6000 \mathrm{yr}$ BP period, in addition to a suit of surface samples, are added to the existing pollen dataset for Maritime Canada. The long sequences were collected with a Livingstone corer (Deevey, 1965), from a raft formed by two aluminum boats linked together with three metal rods. The surface samples were collected with an Ekman dredge. Samples were processed according to the method developed by Erdtman (1960), i.e. digested with $\mathrm{KOH} 10 \%, \mathrm{HF} 49 \%, \mathrm{HCl} 50 \%$ and acetolyzed. Pollen grains of Eucalyptus globulus, an exotic species, were added to the samples to determine pollen concentration, according to the method presented by Benninghoff (1962). Residues were rinsed with butanol and stored in silicon oil. 300 to 500 pollen grains and 100 grains of Eucalyptus globulus were identified and counted for each sample, at a magnification of $40 x$.

Twenty new radiocarbon dates spanning the Holocene of Maritime Canada were obtained using the radiocarbon determination methodology, either conventional or by accelerator (Table II and Appendix). Sections for dating have been chosen in order to pinpoint the $6000 \mathrm{yr}$ BP period and linear interpolation has been used to infer the age of the sections not directly dated.

\section{INTERPRETATION OF THE VEGETATION AT 6000 YR BP}

\section{INTRODUCTORY REMARKS}

The sites that record information on paleovegetation and paleoclimate are indicated in Table $\|$ and Figure 6 which 


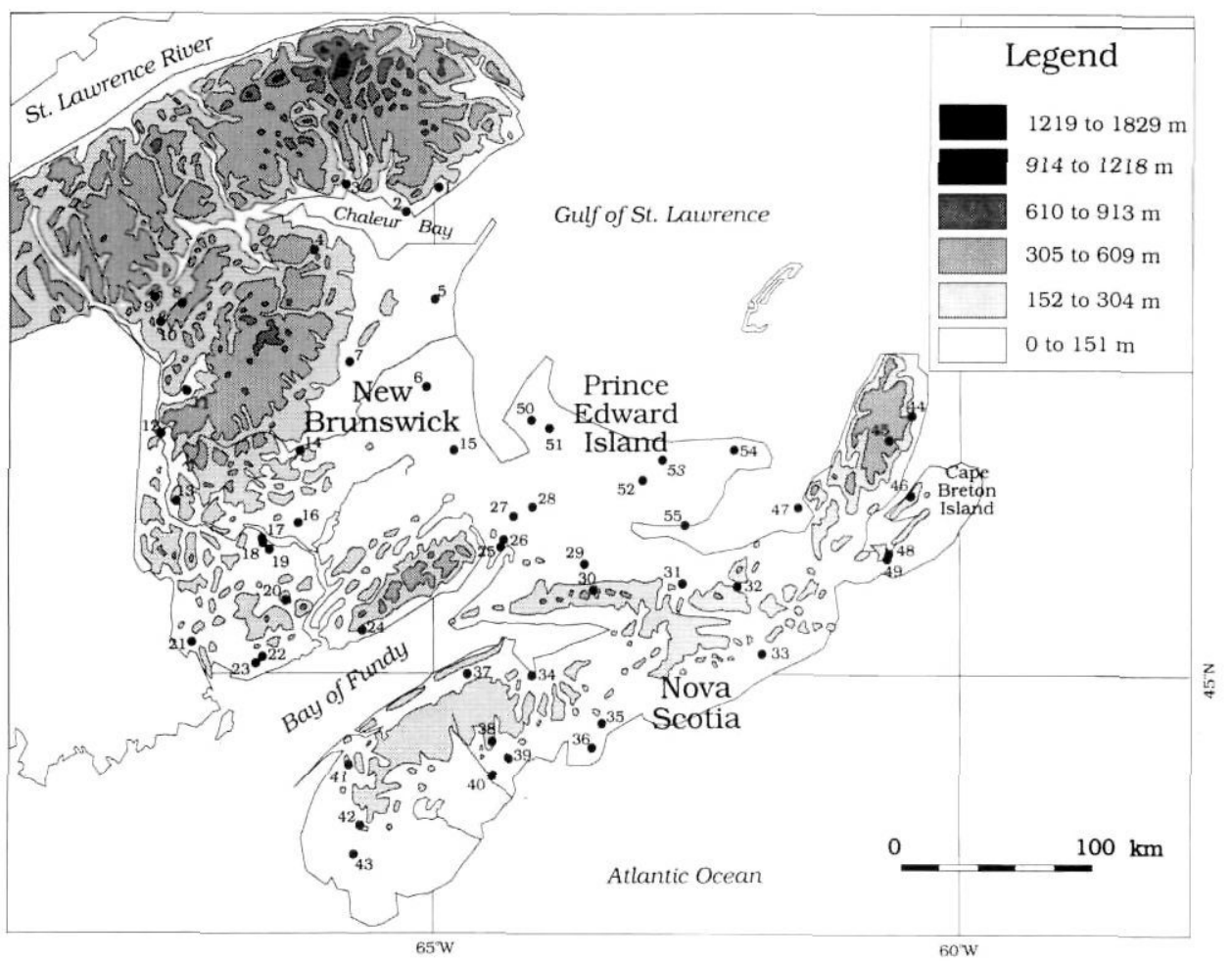

FIGURE 6. Localisation map of fossil sites. The numbers on the map correspond to the numbers on Tables I, II and III.

Localisation des sites fossilifères. Les chiffres correspondent aux numéros des tableaux I, II et III. also features the topography, the main rivers and sea level position (Dyke and Prest, 1987) at $6000 \mathrm{yr}$ BP. Three sites from the northern shore of Chaleur Bay (Québec) are included in order to document past vegetation around this bay. The list of sites is limited, only the sites that yield information on the 6 ka period are presented.

Two major forest types have been defined in a reconstruction of the 6 ka vegetation of the Maritime Canada: the Boreal Forest (BF) and the Mixed Coniferous Deciduous Forest (MCDF). The pollen assemblages of the Boreal Forest are characterized by conifers such as spruce (Picea), pine (Pinus), fir (Abies) and by birch (Betula). The pollen assemblages of the Mixed Coniferous Deciduous Forest are characterized by hardwoods such as maple (Acer), oak (Quercus), elm (UImus), ash (Fraxinus) and by conifers such as fir (Abies), pine (Pinus) and hemlock (Tsuga). This forest type has been further divided into three minor types: MCDF with fir (Abies) (MCDF-A), MCDF with pine (Pinus), including white pine (Pinus strobus) (MCDF-P) and MCDF with hemlock (Tsuga) (MCDF-T). For the representation of the coniferous species within the Mixed Coniferous Deciduous Forest, the following boundaries have been defined: MCDF-T: at least $10 \%$ hemlock, white pine sometimes present in high percentages; MCDF-P: at least $40 \%$ pine including white pine; MCDF-A: at least $1 \%$ fir. According to the relationship between forest composition and pollen rain, the $R$ value, as described by Davis (1963) and applied to Nova Scotia and New Brunswick forests by Livingstone (1968), these pollen percentages correspond roughly to a representation of $5 \%$ for hemlock to $20 \%$ for fir and pine in the deciduous-coniferous forest.
The forest types are dependant on the climatic conditions. The Boreal Forest (BF) is the coldest type. Within the Mixed Coniferous Deciduous Forest (MCDF), the coldest assemblage will be represented by fir as the coniferous species and by maple as the companion hardwood; as the climate improves, pine and hemlock representation rises and so do the variety and abundance of the other hardwoods.

\section{THE VEGETATION AT 6000 YR BP}

Table II for pollen sites and Table III for forest assemblages are to be referred to through the whole section. The migration of white pine in eastern Canada can be traced in the lowlands along the north shore of Chaleur Bay. At sites 1 (Fig. 7) and 2 , only some trees were present, as indicated by the low percentage $(33 \%)$ of this taxon in the pollen diagrams. At site 3 (Fig. 8), white pine occupied an important portion of the landscape, as indicated by the representation of this taxon at this site $(50 \%$ out of $75 \%$ pollen of pine). On the south shore of the bay, pine was also present in valleys as indicated by the representation of pine at site 4 (Fig. 9) which is located at a high elevation $(290 \mathrm{~m})$. This site is characterized by a MCDF with fir as the representative conifer but pine, mainly white pine, reaches values of $35 \%$, indicating that this species was probably present in the valleys. Deciduous species such as maple, ash and elm were also present around the bay.

The vegetation south and northwest of Chaleur Bay 6000 yr BP was a MCDF with white pine in the valleys and fir at higher elevations. Northeast of the bay, the vegetation was a mixed coniferous deciduous forest with fir. White pine 
TABLE lil

Forest assemblages 6000 yr BP

\begin{tabular}{|c|c|c|c|}
\hline No. & Site name & Assemblage & Comments \\
\hline 1 & Caribou L. & MCDF-A & $33 \%$ pine; $1 \%$ fir \\
\hline 2 & à Robin L. & MCDF-A & $33 \%$ pine; $2 \%$ fir \\
\hline 3 & à Raymond L. & MCDF-P & $70 \%$ pine, $55 \%$ white pine \\
\hline 4 & Island L. & MCDF-A & $\begin{array}{l}\text { high elevation } 290 \mathrm{~m}), 25 \% \text { pine; fir on slopes, } \\
\text { pinein valleys, hemlock max. }\end{array}$ \\
\hline 5 & Tracadie B. & MCDF-T & $10 \%$ hemlock; anomalous date \\
\hline 6 & Escuminac B. & MCDF-T & no date but well-defined hemlock curve \\
\hline 7 & Shaddick L. & MCDF-P & $58 \%$ pine, $10 \%$ white pine, hemlock max. \\
\hline 8 & St.Quentin B. & $\mathrm{BF}$ & spruce and pine (jack pine?) \\
\hline 9 & Grant Falls S. & MCDF-P & $60 \%$ pine, $20 \%$ white pine \\
\hline 10 & Route $17 \mathrm{~B}$. & MCDF-P & $40-50 \%$ pine; $2-5 \%$ fir \\
\hline 11 & Roulston L. & MCDF-A & $\begin{array}{l}30 \% \text { pine; fir on slopes, pine in valleys; } \\
\text { hemlock max. } 5500 \mathrm{BP}\end{array}$ \\
\hline 12 & Hartiand $\mathrm{B}$. & MCDF-P & $50 \%$ pine \\
\hline 13 & Woodstock B. & MCDF-P & $50-70 \%$ pine \\
\hline 14 & Timber Pond B. & MCDF-T & no date but hemlock typical curve \\
\hline 15 & Birch Ridges B. & MCDF-T & hemlock at $10 \%$ around 6700 \\
\hline 16 & Bull Pasture B. & MCDF-T & anomalous date but hemlock typical curve \\
\hline 17 & Fredericton B. & MDCF-? & useless \\
\hline 18 & North Renous B. & MCDF-P & $60 \%$ pine \\
\hline 19 & Regent Street B. & MCDF-P & $50 \%$ pine \\
\hline 20 & Bacon L. & MCDF-T & $15 \%$ hemlock \\
\hline 21 & Basswood Road L. & MCDF-T & $30 \%$ hemlock; typical curve \\
\hline 22 & St. Andrews B. & MCDF-T & $25 \%$ hemlock; typical curve \\
\hline 23 & Little L. & MCDF-T & $25-30 \%$ hemlock, anomalous date \\
\hline 24 & Spruce Lake B. & MCDF-T & $25-30 \%$ hemlock; typical curve \\
\hline 25 & Portey P. & MCDF-T & $12-30 \%$ hemlock; typical curve \\
\hline 26 & Wood's P. & MCDF-T & $25-30 \%$ hemlock; typical curve \\
\hline 27 & Collins L. & MCDF-T & $20 \%$ hemlock, typical curve \\
\hline 28 & Poucette L. & MCDF-T & $27 \%$ hemlock \\
\hline 29 & Wigmore L. & MCDF-T & $16 \%$ hemlock \\
\hline 30 & Folly B. & MCDF-T & $20 \%$ hemlock; typical curve \\
\hline 31 & Chance Harbour L. & MCDF-T & $15 \%$ hemlock, typical curve \\
\hline 32 & Indian L. & MCDF-T & $15 \%$ hemlock \\
\hline 33 & Pye L. & MCDF-T & $18 \%$ hemlock \\
\hline 34 & Shaw's B. & MCDF-T & $15 \%$ hemlock; well-dated site \\
\hline 35 & Silver L. & MCDF-T & $15-20 \%$ hemlock, well dated site \\
\hline 36 & Penhorn L. & MCDF-T & $25 \%$ hemlock \\
\hline 37 & Caribou B. & MCDF-T & $30 \%$ hemlock; typical curve \\
\hline 38 & Canoran L. & MCDF-T & $20-30 \%$ hemlock; typical curve \\
\hline 39 & Minard L. & $?$ & unable to interpret, local influence \\
\hline 40 & Oak Hill L. & MCDF-T & $10 \%$ hemlock; date at $6230 \mathrm{BP}$ \\
\hline 41 & Everitt L. & MCDF-T & $25 \%$ hemlock; typical curve \\
\hline 42 & Bower L. & MCDF-T & $8 \%$ hemlock \\
\hline 43 & Curry $P$. & MCDF-T & $20 \%$ hemlock \\
\hline 44 & Wreck Cove L. & MCDF-A & high elev. $(335 \mathrm{~m})$, date from site 45 \\
\hline 45 & Timber L. & MCDF-A & high elev. $(386 \mathrm{~m})$ hemlock max $5340 \mathrm{BP}$ \\
\hline 46 & McDougal L. & MCDF-A & no date; regional chronology used \\
\hline 47 & Port Hood Island S. & MCDF-P & $40 \%$ pine, no hemlock \\
\hline 48 & Salmon River L. & MCDF-A & hemlock max. at $5540 \mathrm{BP}$ \\
\hline 49 & Gillis L. & MCDF-A/T & no date, Salmon River L. date used \\
\hline 50 & Portage B. & MCDF-T & $15 \%$ hemlock; date interpolated \\
\hline 51 & East Bideford B. & MCDF-T & $15 \%$ hemlock \\
\hline 52 & Mermaid B. & MCDF-T & $15 \%$ hemlock; date interpolated \\
\hline 53 & MacLaughlin P. & MCDF-T & $15 \%$ hemlock \\
\hline 54 & East Baltic B. & MCDF-T & $10 \%$ hemlock \\
\hline 55 & Iris Station B. & MCDF-P & $45 \%$ pine, $20 \%$ white pine \\
\hline
\end{tabular}




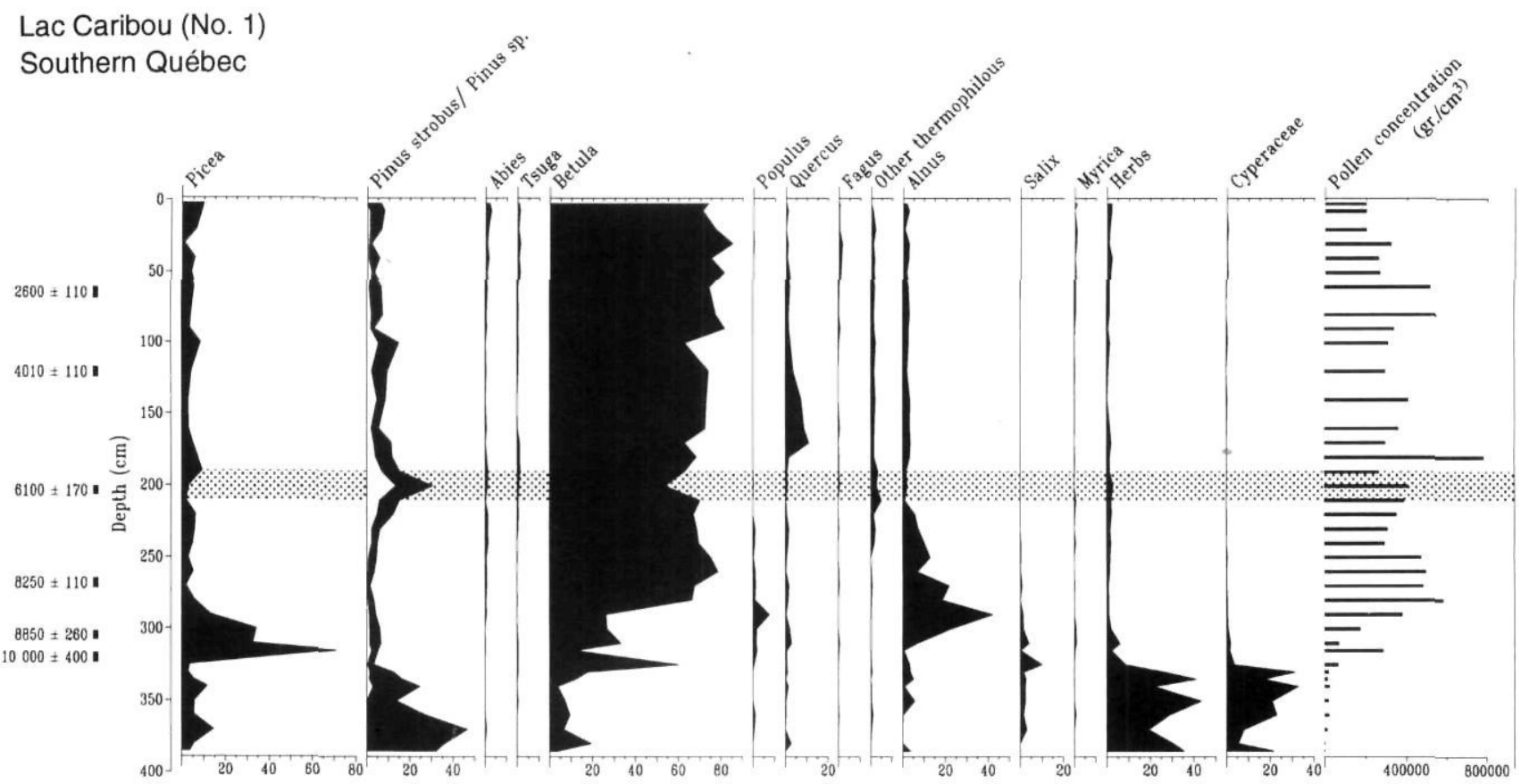

FIGURE 7. Pollen diagram (percentages) for Lac Caribou (site 1), southern Québec. Source: Jetté and Richard (1992).

Diagramme de pourcentages polliniques du lac Caribou (site $\left.n^{\circ} 1\right)$, dans le sud du Québec. Source : Jetté et Richard (1992).

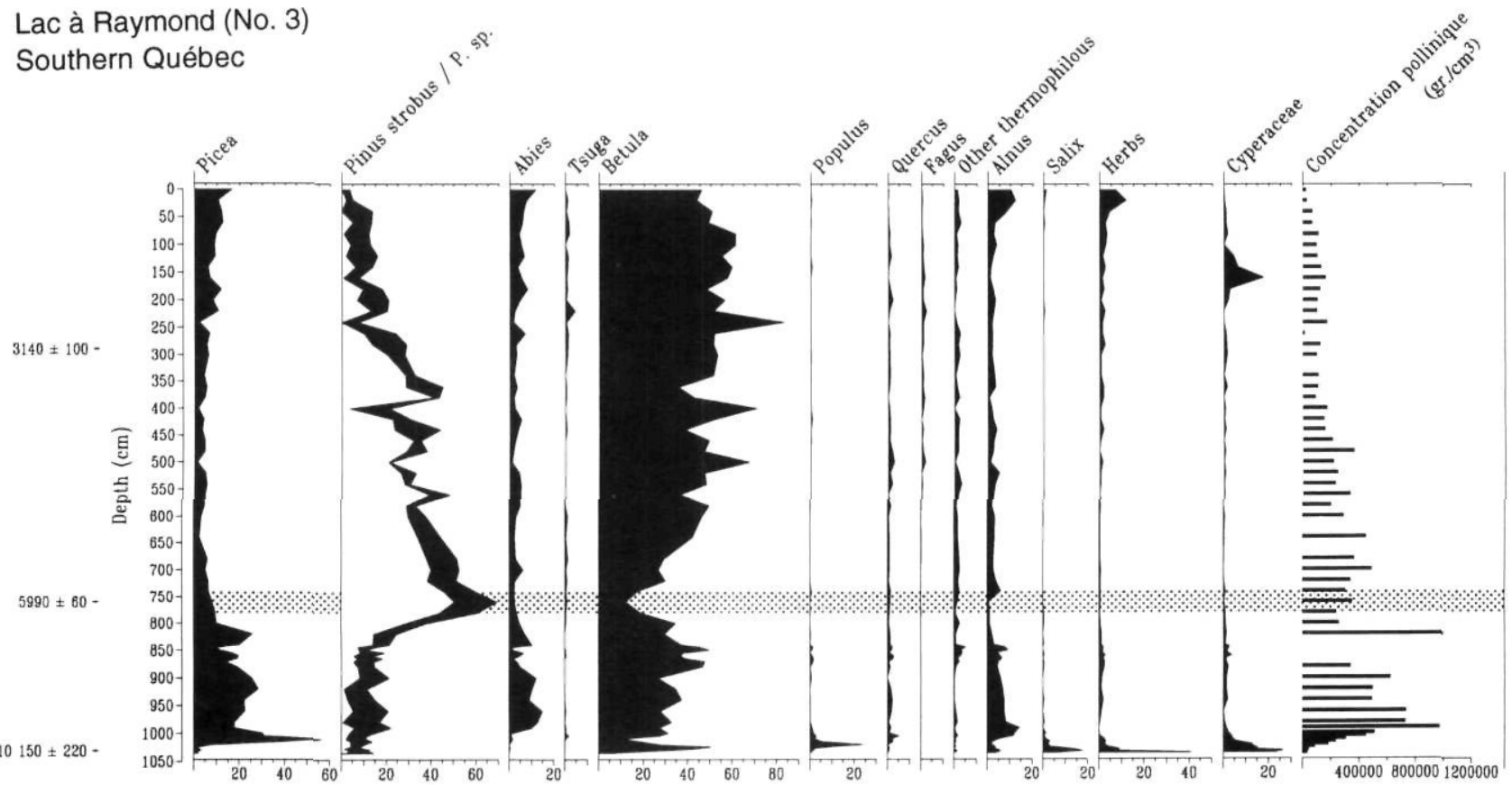

FIGURE 8. Pollen diagram (percentages) for Lac à Raymond (site 3), southern Québec. Source: Jetté and Richard (1992).

Diagramme de pourcentages polliniques du lac à Raymond (site $n^{\circ}$ 3), dans le sud du Québec. Source : Jetté et Richard (1992).

forests did not move eastward from site 2 or northward up the Gaspésie plateau.

In northwest New Brunswick, pine reached $50 \%$ at site 9 (Fig. 10) circa $6000 \mathrm{yr}$ BP. The presence of some thermophilous trees including maple (Acer) indicates that a MCDF with pine, including white pine, was present at this site. Site 10 is not dated and might be too young but, if not, the percentage of pine at that site would reinforce the interpretation made for site 9 . It is difficult to interpret the bog sequence at site 8 because pine pollen has not been identified at that site. Since the site is at a high elevation with a relatively high percentage of spruce $(40 \%)$ in the sediment $6000 \mathrm{yr} \mathrm{BP}$, it is probable that the type of pine present was Jack Pine (Pinus banksiana). If so, the vegetation 


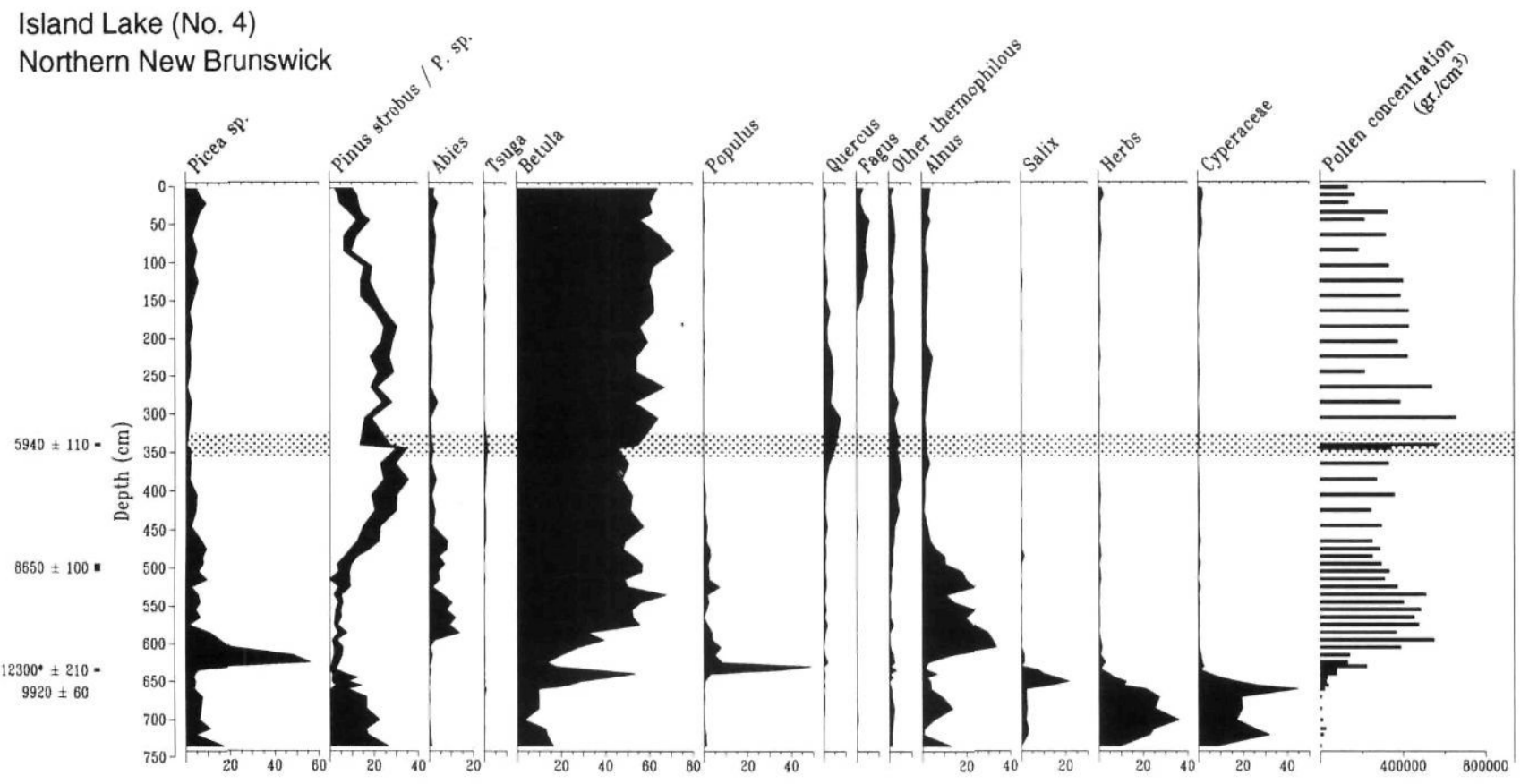

FIGURE 9. Pollen diagram (percentages) for Island Lake (site 4), northeast New Brunswick. Source: Jetté et al. (in prep.).
Diagramme de pourcentages polliniques de Island Lake (site $n^{\circ} 4$ ), dans le nord-est du Nouveau-Brunswick. Source : Jetté et al. (en prép.).

Grand Falls Section (No. 9)

Northwest New Brunswick

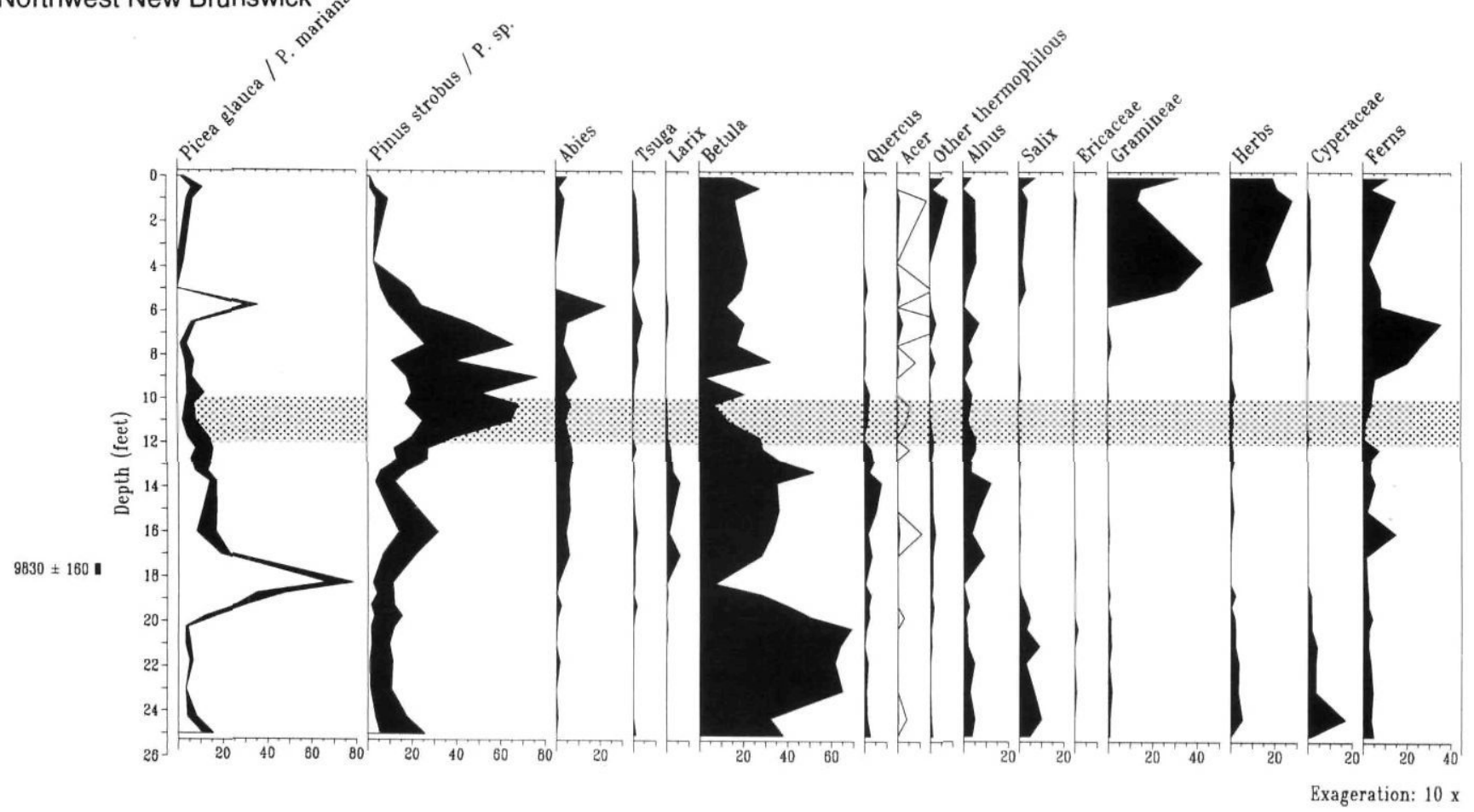

FIGURE 10. Pollen diagram (percentages) for Grand Falls (site 9) section, northwest New Brunswick. Source: Terasmae, 1973.
Diagramme de pourcentages polliniques de Grand Falls (site $n^{\circ}$ 9), dans le nord-est du Nouveau-Brunswick. Source: Jetté et al. (en prép.). 
surrounding the site was a boreal forest. The basal half of the cores at sites 8 and 9 was deposited in a cold and wet environment, dominated by fir, tamarack (Larix) and sedges (Cyperaceae). From circa 6000 BP, conditions became drier and warmer and pine representation increases dramatically at both sites. In northwest New Brunswick the vegetation was, 6000 yr BP, a MCDF with pine. A boreal forest likely occupied higher elevations on the plateau (site 8) at that time, as it does today (Rowe, 1972).

Pine was late to migrate into northern New Brunswick and into the northern part of Chaleur Bay (between 7000 and $6000 \mathrm{yr}$ BP at site 1 Fig. 7, 2 and 3, Fig. 8; circa 6000 yr BP at site 9, Fig. 10), whereas it was present as early as $9000 \mathrm{yr}$ BP in southern New Brunswick (Mott, 1975), in southern Québec and southern Ontario (Anderson, 1985). The delay of pine migration in northern New Brunswick until 6000 BP could well be linked with climatic constraints.

Sites 11 (Fig. 11), 12, and 13 from the St. John Valley are representative of a MCDF with presence of fir (site 11) or pine (sites 12 and 13). Between 8000 and 5700 yr BP, the vegetation at site 11 (Roulston Lake) was a MCDF characterized by fir. Some pollen from thermophilous species are present but the assemblage is the coldest of the mixed forest. Circa $6500 \mathrm{BP}$, pine was probably present in the valleys, as indicated by high percentages of pine pollen, $39 \%$, including $26 \%$ of white pine. Site 12 is characterised by high percentages of pine pollen circa 6000 yr BP, prior to the rise in hemlock dated at nearby Roulston Lake at $5480 \pm 150$ BP. Site 13 records $70 \%$ of pine 6000 yr BP.
Further south, on the south shore of the St. John River, sites 18 and 19 record between 50 and $70 \%$ pine. Hemlock is present at both sites but does not reach the $10 \%$ level. Site 16 , north of the River, records $12 \%$ of hemlock. The basal date obtained at that site is suspected to be anomalous. The representation of hemlock in lakes in southern New Brunswick (Mott, 1975) shows a typical well-defined bimodal curve. The basal mode of the curve has been dated, at site 21 (Fig. 14), between 7000 and 4800 yr BP. Therefore the age of the first mode of hemlock at site 16 should range between these ages. Terasmae (1973) and Mott (1975) reported a first incursion of hemlock in northern New Brunswick around 7000 yr BP. We believe, on the evidences put forward by the long sequence dated at Roulston Lake, that Terasmae's early chronology reflects anomalous dates in this area; hemlock did not reach its maximum before 5500 yr BP along the St. John Valley.

In eastern New Brunswick, hemlock representation of more than $10 \%$ is recorded at sites 5,6 and 15 . The chronology for the hemlock maximum rests on two sites in this area: sites 4 (Fig. 9) and 7 (Fig. 12). Site 4 has been interpreted as a MCDF with fir and site 7 as a MCDf with pine, but the dates for the hemlock maximum dated circa 6000 at both sites are useful to establish a regional chronology for this taxon. In eastern New Brunswick, a MCDF with hemlock was colonizing low areas adjacent to the coast, which was seaward of the present coast, as indicated by the sea level map of $6000 \mathrm{yr}$ BP. Hemlock did not reach the Chaleur Bay area, as indicated by the low curve for this

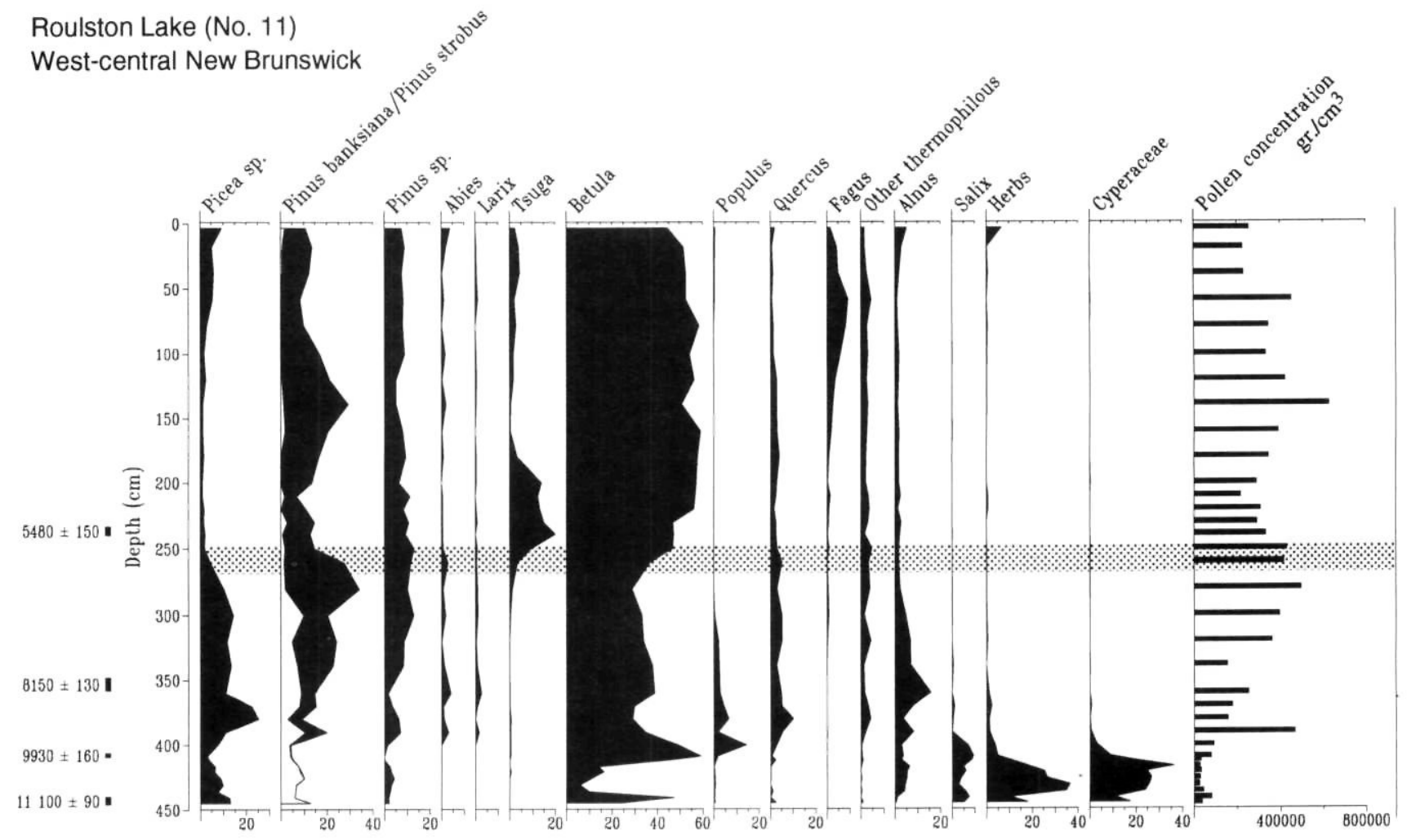

FIGURE 11. Pollen diagram (percentages) for Roulston Lake (site 11), west-central New Brunswick. Sources: Mott et al. (1986); this paper.
Diagramme de pourcentages polliniques de Roulston Lake (site $n^{\circ}$ 11), dans le centre-ouest du Nouveau-Brunswick. Source : Mott et al. (1986) et présent article. 
species at sites 1 (Fig. 7), 2, 3 (Fig. 8) and 4 (Fig. 9). Central New Brunswick (site 14) and the southern section of the St. John River were covered by a MCDF with hemlock at that time.

In southern New Brunswick, sites 20 (Fig. 13), 21 (Fig. 14), 22, 23, 25, 26, 27 and 28 (Fig.15) record hemlock percentages ranging from 10 to $40 \%$, indicating that a MCDF with hemlock was occupying this area $6000 \mathrm{yr}$ BP.

In Prince Edward Island, pollen records at sites 50, 51, 52,53 and 54 indicate that the vegetation prevalent $6000 \mathrm{yr}$ BP was a MCDF with hemlock as the characteristic tree. Pollen representation of this species reached $30 \%$ between 7000 and $5000 \mathrm{yr}$ BP (Anderson, 1980; 1985) at these sites. A high representation of pine $(45 \%)$ is observed at site 55, near the 6 ka coast (Frankel and Crowl, 1961). Nowadays, hemlock does not grow close to the coast, it is likely that the situation was the same $6000 \mathrm{yr}$ BP.

In Nova Scotia, all the sites located on the mainland $(29$ (Fig. 16), 30, 31 (Fig. 17), 32 (Fig. 18), 33 (Fig. 19), 34, 35, $36,37,38,40,41$ and 42 (Fig. 20) record hemlock values close to or greater than $10 \%$. Even sites located at high elevations have high percentages of hemlock. As sea level was lower than today, the sites were located farther from the sea. The only site close to the coast $6000 \mathrm{yr}$ BP was site 34 . This site is peculiar and characterized by a strong interaction between hemlock and pine, suggesting that the proximity of the sea was detrimental to hemlock at that site, as was the case at site 55, on Prince Edward Island.

Hemlock arrival on the northwest coast of Cape Breton Island was delayed until $5340 \pm 130$ (Beta-66130) at site 45 (Fig. 21), located at a high elevation (386 $\mathrm{m}$ a.s.I.). Therefore, $6000 \mathrm{yr} \mathrm{BP}$, as demonstrated at sites 44,45 (Fig. 21) and 46 , the forest of the Cape Breton Plateau was a MCDF with fir as the dominant conifer. Hemlock arrived circa 5540 yr BP at sites 48 and 49 , on the eastern side of the Island. Site 47 , located close to the sea, records high percentages of pine and no hemlock. As for sites 55 and 34 , the proximity of the sea seems to have prevented the development of a hemlock-dominated MCDF at that site.

\section{TENTATIVE RECONSTRUCTION OF THE VEGETATION OF MARITIME CANADA 6000 YR BP}

Results compiled in Table II are used to generate a tentative reconstruction of the vegetation of Maritime Canada 6000 yr BP (Fig. 22), in terms of Boreal or Mixed Coniferous-Deciduous forests dominated by hemlock (MCDF-T), pine (MCDF-P) or abies (MCDT-A). Tentative boundaries between forest types are proposed.

Cape Breton Island, 6000 yr BP, was covered by a MCDF with fir. Mainland Nova Scotia, Prince Edward Island, southern and eastern New Brunswick were covered by a MCDF with hemlock. Hemlock was probably not growing too close to the sea, as indicated by sites 47 and 55 , sites located close to the shoreline and characterized by a MCDF with pine.

The vegetational cover in northwest New Brunswick is more difficult to interpret because of the changing topography and because of the limited number of palynological studies available for this area. The forest was a MCDF with white pine (MDCF-P) at low elevations along the St. John River, in the northern part of New Brunswick and in southern Québec. Up slope, as indicated by Island Lake (site 4; Fig. 9; $290 \mathrm{~m}$ a.s.l.), hemlock was replaced by fir. At higher elevations, as indicated by site 8 (Tables II and III), a boreal forest was probably present, as it is today on the New Brunswick Plateau.
FIGURE 12. Pollen diagram (percentages) for Shaddick Lake (site 7), east-central New Brunswick. Source: this paper.

Diagramme de pourcentages polliniques de Shaddick Lake (site $n^{\circ} 7$ ), dans le centre-est du Nouveau-Brunswick. Source : présent article.

FIGURE 13. Pollen diagram (percentages) for Bacon Lake (site 20), south-central New Brunswick. Source: this paper.

Diagramme de pourcentages po/liniques de Bacon Lake (site $\left.n^{\circ} 20\right)$, dans le centre-sud $d u$ Nouveau-Brunswick. Source : présent article.
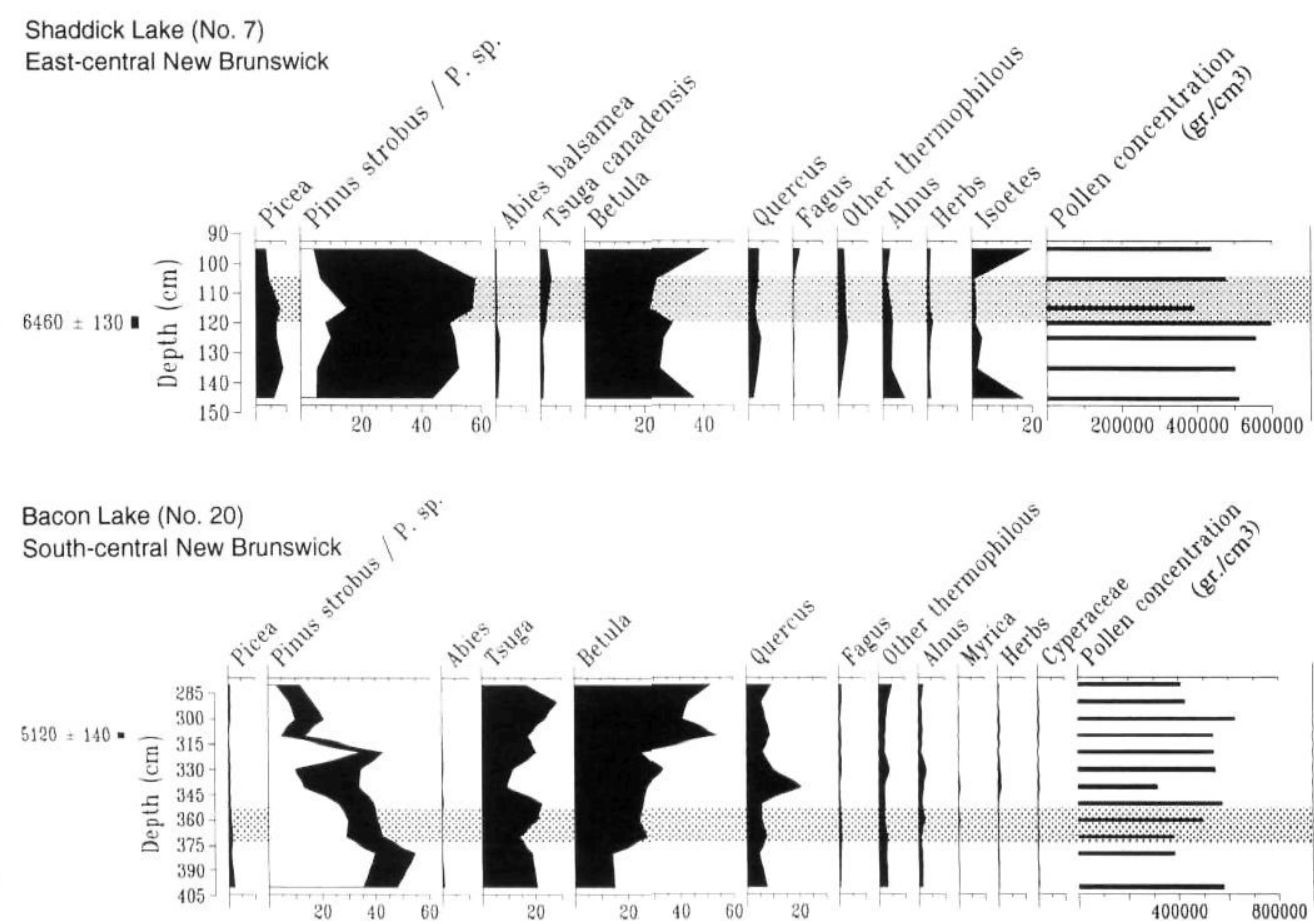
Basswood Road Lake (No. 21) Southwest New Brunswick

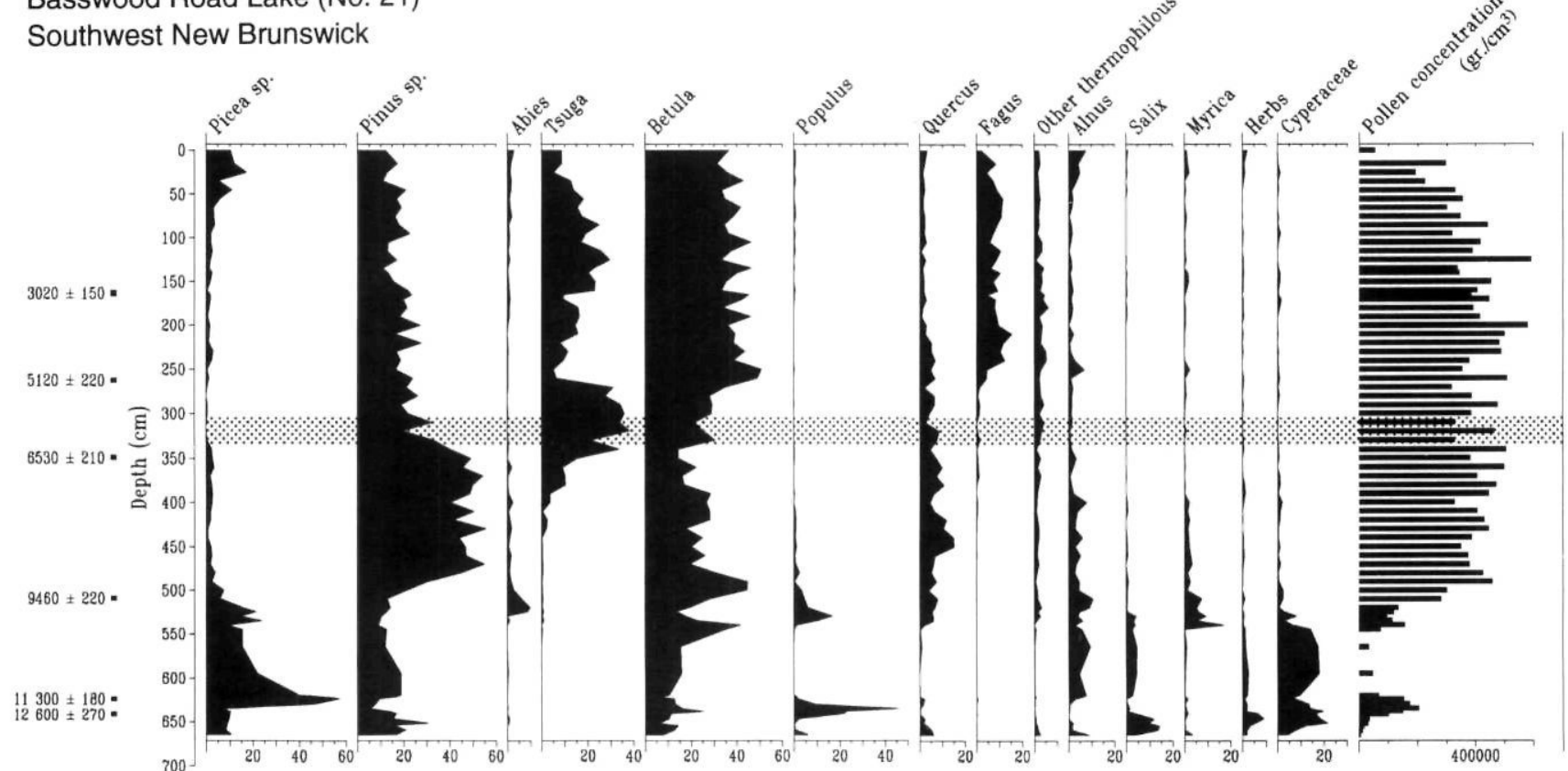

FIGURE 14. Pollen diagram (percentages) for Basswood Road Diagramme de pourcentages polliniques de Basswood Road Lake Lake (site 21), southwest New Brunswick. Source: Mott (1975). (site $\left.n^{\circ} 21\right)$, dans le sud-ouest du Nouveau-Brunswick. Source : Mott (1975).

Poucette Lake (No. 28)

South-central New Brunswick

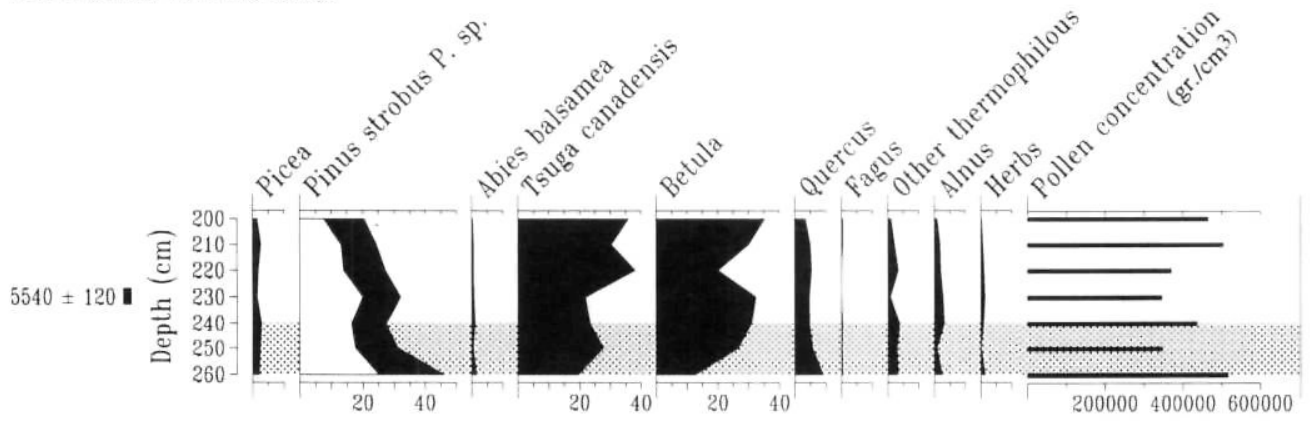

FIGURE 15. Pollen diagram (percentages) for Poucette Lake (site 28), south-east New Brunswick. Source: this paper.

Diagramme de pourcentages polliniques de Poucette Lake (site $n^{\circ}$ 28), dans le sud-est du NouveauBrunswick. Source : présent article.

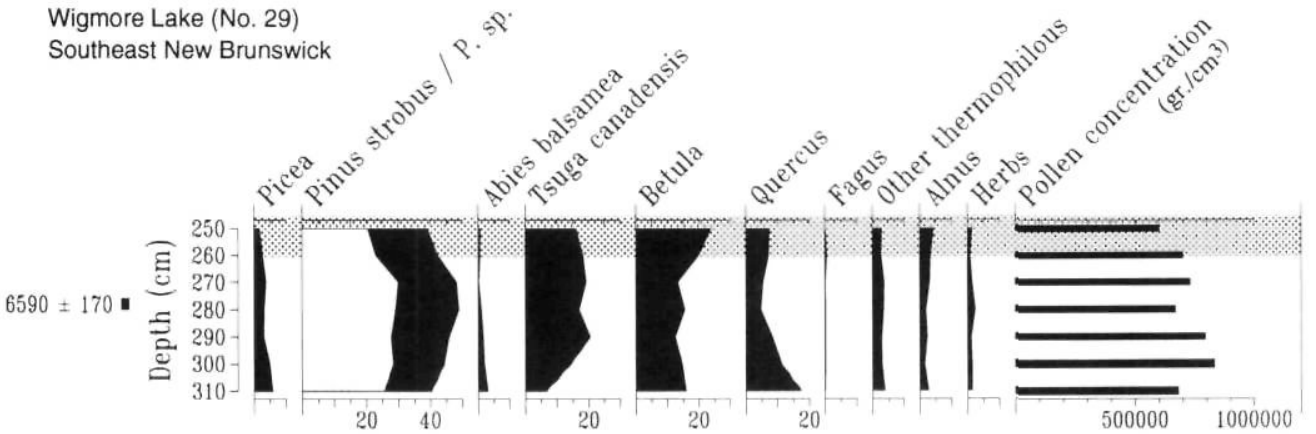

FIGURE 16. Pollen diagram (percentages) for Wigmore Lake (site 29), southeast New Brunswick. Source: this paper.

Diagramme de pourcentages polliniques de Wigmore Lake (site $n^{\circ}$ 29), dans le sud-est du NouveauBrunswick. Source : présent article.

\section{HEMLOCK FLUCTUATIONS DURING THE HOLOCENE}

Hemlock arrived circa 7000 yr BP in western and southern Nova Scotia and slightly later in the eastern part of the province. It reached its maximum range circa 5500 yr BP in northwest New Brunswick and on Cape Breton Island. This species declined drastically and in a synchronous way across North America around $4800 \mathrm{yr}$ BP following, according to Davis (1981), a pathogen attack. It recovered between 4000 and 3000 yr BP but never again reached values observed previously in middle Holocene time.

Prior to the 4800 BP hemlock decline, an earlier decline of this same species can be observed on pollen diagrams 


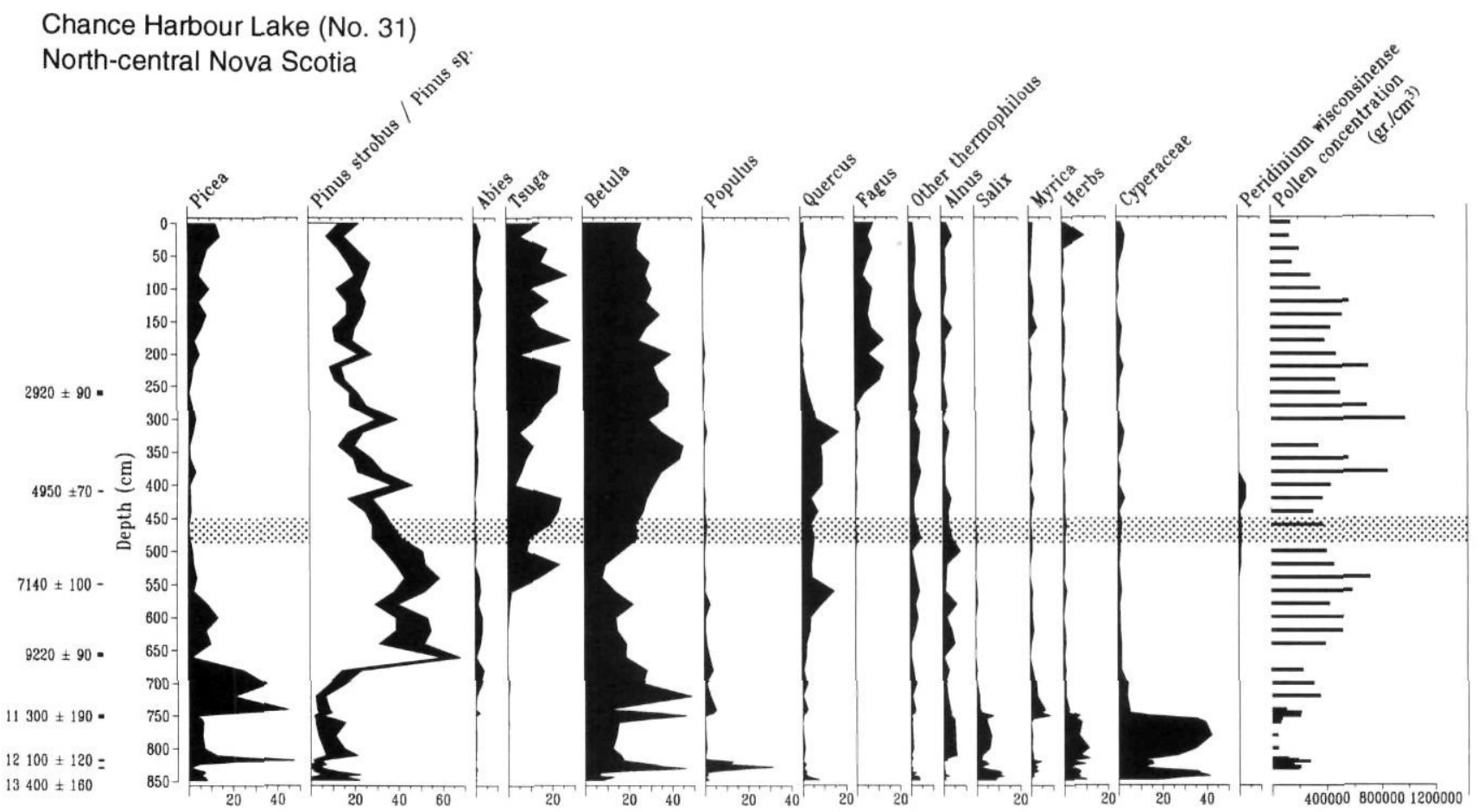

FIGURE 17. Pollen diagram (percentages) for Chance Harbour Diagramme de pourcentages polliniques de Chance Harbour Lake Lake (site 31), north-central Nova Scotia. Source: Jetté and Mott, (site $\left.n^{\circ} 31\right)$, dans le centre-nord de la Nouvelle-Écosse. Source : 1989; this paper. Jetté et Mott (1989); présent article.

FIGURE 18. Pollen diagram (percentages) for Indian Lake (site 32), eastern Nova Scotia. Source: this paper.

Diagramme de pourcentages polliniques de Indian Lake (site $n^{\circ}$ 32), dans l'est de la NouvelleÉcosse. Source : présent article.

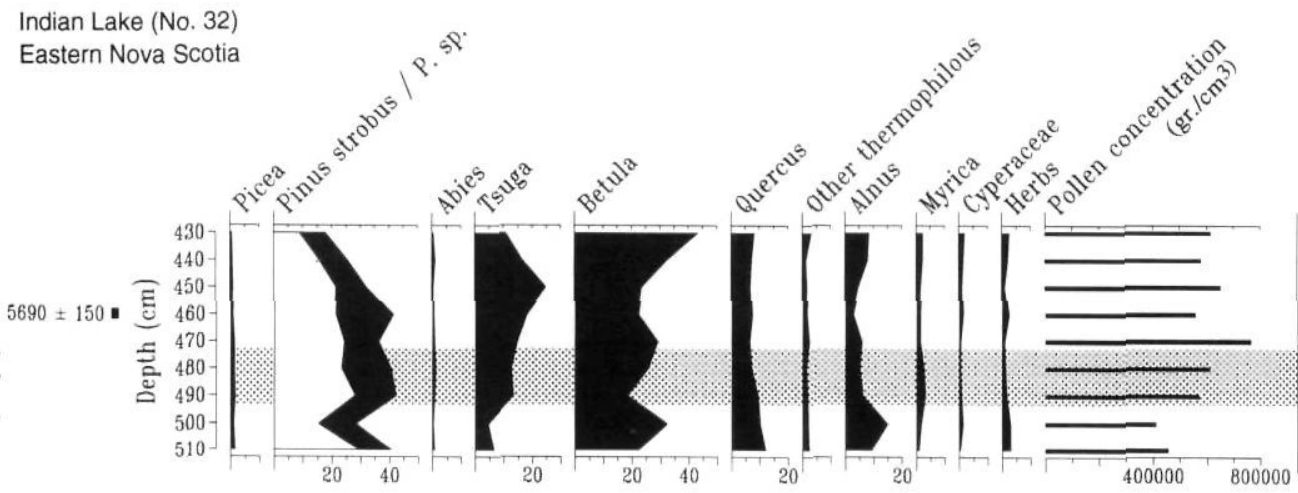

from southern New Brunswick (Fig. 14; Table IV), mainland Nova Scotia (Figs. 17 and 20, Table IV) and Prince Edward Island (Table IV). The beginning of this earlier decline, which was of short duration, has been dated at $6540 \pm 120$ $\mathrm{BP}$ at site 31 (Fig. 17). At the time of the 6500 BP hemlock decline, percentages of hemlock pollen fell below the $10 \%$ level at some sites, indicating that the number of hemlock trees was lower than $5 \%$ in the forest during that time. By circa 6000 BP, hemlock had recovered.

Table IV lists the sites where the $6500 \mathrm{BP}$ hemlock decline is observed and the sites where a sediment change occurs during this period. In southern New Brunswick and in north and northeast Nova Scotia, hemlock is replaced by birch and alder. In western Nova Scotia, a brief spruce (Picea) peak parallels the hemlock decline. In Prince Edward Island, hemlock is replaced by birch. At some locations the percentage of oak (Quercus) rises, indicating possibly an opening of the landscape. Pine seems either unaffected or does not take advantage of the hemlock decline. Three possible causes could explain this sudden decline in hemlock 6500 yr BP: a disease, a catastrophic event such as a forest fire or a hurricane, or a climatic deterioration. A pathogen attack affecting only hemlock, as has been postulated by Davis (1981), as the cause of the 4800 BP hemlock decline, resulted in an increase in pine replacing hemlock in the landscape. This is not the case for the 6500 BP decline as pine does not take advantage over hemlock.

A catastrophic event such as a forest fire or a hurricane could destroy mature trees in a forest. Interspecific competition and species succession would eventually bring the forest back to its initial status, assuming favourable environmental conditions. This explanation would account for 


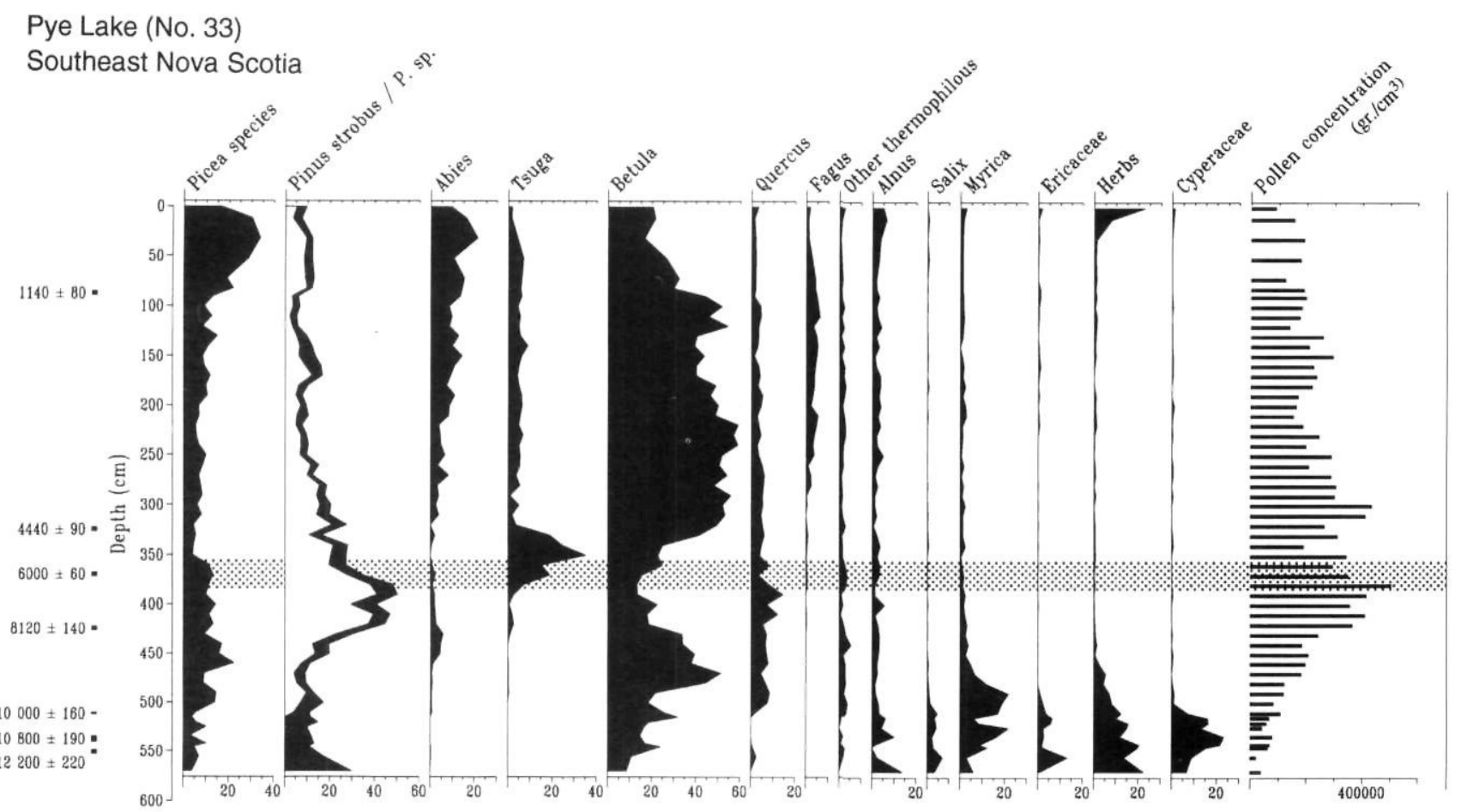

FIGURE 19. Pollen diagram (percentages) for Pye Lake (site 33), southeast Nova Scotia. Source: this paper.

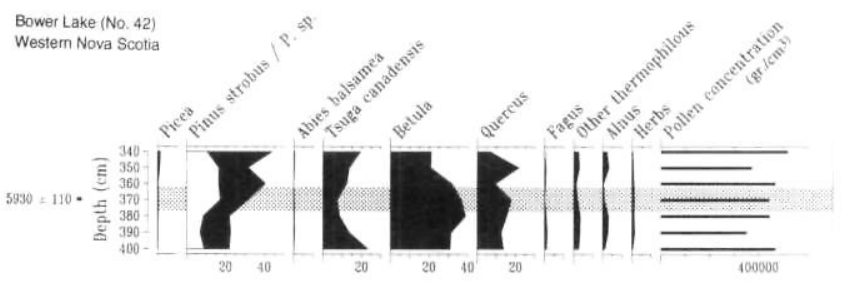

FIGURE 20. Pollen diagram (percentages) for Bower Lake (site 42), western Nova Scotia. Source: this paper.

Diagramme de pourcentages polliniques de Bower Lake (site $n^{\circ}$ 42), dans l'ouest de la Nouvelle-Écosse. Source: présent article.

the presence of some transitional species such as alder (Alnus), willow (Salix), Myrica and spruce (Picea). However, hemlock and pine are still present in the forest and 500 years for a recovery to initial conditions is too long since hemlock trees start producing pollen between 20 and 60 years of age (Marie-Victorin, 1964). This catastrophic event would also have affected a large territory: all of Nova Scotia, all of Prince Edward Island and the southern part of New Brunswick. This is a huge territory to cover for a forest fire or for a hurricane, unless climatic conditions were favouring the repetition of such catastrophic events.

Another cause to explain the $6500 \mathrm{BP}$ hemlock decline is climatic change. Hemlock prefers cool and moist conditions (Marie-Victorin, 1964). A climatic deterioration for this species could mean cold, warm and/or dry conditions. We can eliminate the cold scenario because, at that time, white pine forests were at the foot of the Gaspésie Plateau,
Diagramme de pourcentages polliniques de Pye Lake (site $n^{\circ} 33$ ), dans le sud-est de la Nouvelle-Écosse. Source: présent article.

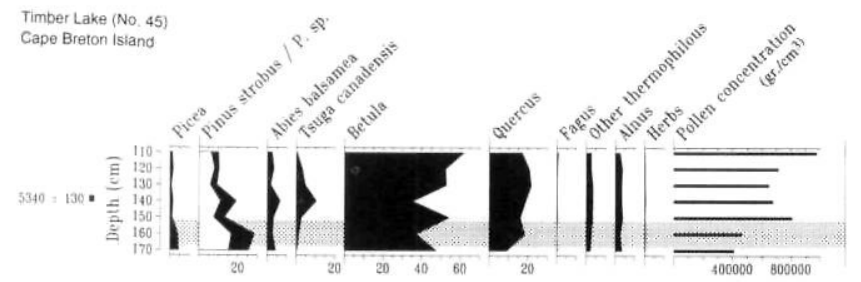

FIGURE 21. Pollen diagram (percentages) for Timber Lake (site 45), Cape Breton Highlands. Source: this paper.

Diagramme de pourcentages polliniques de Timber Lake (site $n^{\circ}$ 45), dans les hautes terres du Cap-Breton. Source : présent article.

indicating that it was probably warmer than today in Maritime Canada. In southern New Brunswick, eastern Nova Scotia and Prince Edward Island, the species that benefited from the hemlock decline were birch and alder (Table IV). In western Nova Scotia, hemlock was replaced by spruce, birch and willow. These species are usually indicative of cold and wet conditions. However, drought conditions would reduce water levels in the lakes thereby exposing lake bottom for colonisation by birch, alder and willow. In this context, these species would indicate dry conditions. Also, in a drought scenario, forest fires will increase, spruce will colonize areas after fires as a transition species and will soon be replaced by hemlock following the dry spell. This is what is observed at sites $35,38,41$ and 43 (Tables II and III). At site 43 , the charcoal concentration has been calculated and shows high percentages of charcoal during this period. Indications of dry conditions during this period are 
TABLE IV

Vegetation and sediment changes circa 6300 yr BP

\begin{tabular}{|c|c|c|c|}
\hline No. & date & replacement species & comments \\
\hline 9 & ca. 6000 & & $\begin{array}{l}\text { sediment change: from fine detritus gyttja to } \\
\text { coarse detritus gyttja, to peat. }\end{array}$ \\
\hline 12 & ca .6000 & & $\begin{array}{l}\text { sediment change: from marl gyttja to gyttja, } \\
\text { to peat. }\end{array}$ \\
\hline 21 & ca. 6000 & birch & \\
\hline 25 & $?$ & birch, alder & high spores content \\
\hline 27 & $?$ & birch, ash, oak & charcoal present \\
\hline 31 & $6500-6000$ & alder, birch, thermophilous & Peridinium wisconsinense; high spores content. \\
\hline 33 & 5800 & birch, oak, spruce & \\
\hline 34 & 6300 & & sediment change: peat replacing gyttja \\
\hline 35 & 6200 & birch, spruce & high spores content \\
\hline 38 & $?$ & oak, willow, birch, spruce, myrica & $\begin{array}{l}\text { sediment change: fine detritus gyttja replacing } \\
\text { algal gyttja }\end{array}$ \\
\hline 41 & 6300 & birch, spruce, carpinus/ostrya & \\
\hline 43 & $?$ & spruce, birch, non-arboreal & $\begin{array}{l}\text { sediment change: peat replacing gyttja; } \\
\text { high charcoal content }\end{array}$ \\
\hline 49 & ca. 6000 & birch & \\
\hline 51 & ? & birch & \\
\hline 52 & $?$ & birch & \\
\hline 54 & $?$ & birch & \\
\hline
\end{tabular}

FIGURE 22. Tentative reconstruction of the vegetation of Maritime Canada 6000 yr BP Source: this paper. MCDF-T = Mixed coniferous-deciduous forest with hemlock; MCDF-P = Mixed coniferous-deciduous forest with pine; MCDF-A = Mixed coniferous-deciduous forest with fir; $\mathrm{BF}=$ Boreal Forest.

Reconstitution du paysage végétal des provinces maritimes à 6000 BP. Source: présent article. $M C D F-T=$ forêt mixte de conifères et de feuillus dominée par la pruche; $M C D F-P=$ forêt mixte de conifères et de feuillus dominée par le pin; $M C D F-A$ = forêt mixte de conifères et de feuillus dominée par le sapin ; $B F=$ Forêt boréale.

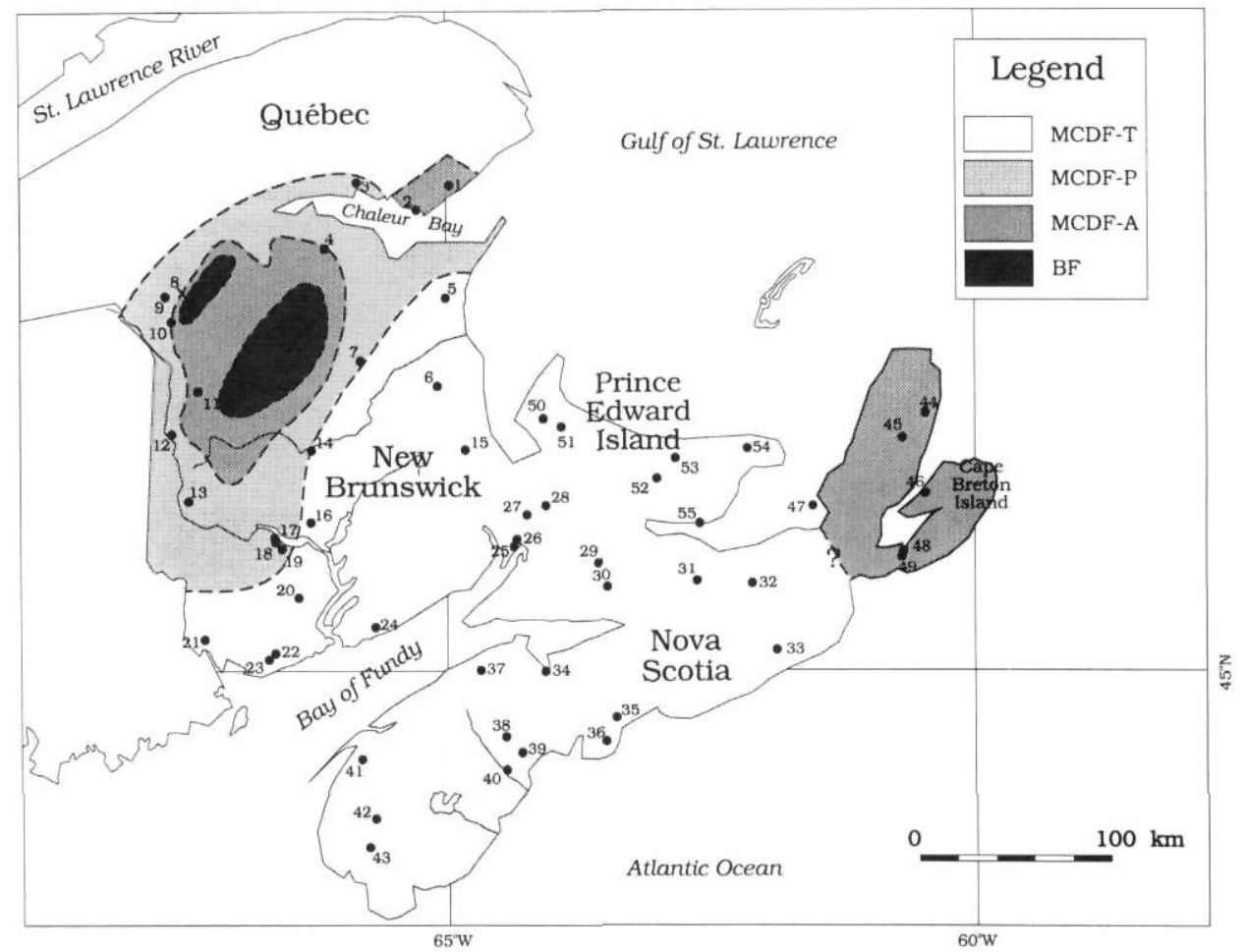

also observed in the sediment columns at some sites. For example, a switch from fine detritus gyttja to coarse detritus gyttja (site 9; Table IV), from gyttja to aquatic peat (site 12; Table IV), from algal gyttja to fine detritus gyttja (site 38; Table IV) and from gyttja to peat reverting to gyttja after the dry spell (site 43; Table IV). Another indication is found at site 31 (Fig. 17) where the occurrence of the freshwater dinoflagellate Peridinium wisconsinense (north of its present distribution range) from circa 7000 to $4800 \mathrm{yr}$ BP, indicates that the temperature of the water was, at that time, warmer than today, possibly because the climate was warmer and/ or the water level was lower than today.

From circa 6500 to $6000 \mathrm{BP}$, a warm-dry period influenced the composition of the vegetation, replacing hemlock by birch, shrubs and spruce in Maritime Canada. This warmdry period was highly favourable to the expansion of white 
pine in eastern Canada where it reached its maximum Holocene range north of Chaleur Bay.

\section{CLIMATIC RECONSTRUCTION}

Nowhere today in Maritime Canada does the representation of pine and hemlock exceed $40 \%$ and $20 \%$ as it did during the 6 ka period when the percentages of these taxa reached up to $75 \%$ and $40 \%$, indicating more representation of these species in the landscape. The best modern analogues for the fossil pollen assemblages of the $6 \mathrm{ka}$ period in Maritimes Canada are found today in the New England states, as indicated by the surface samples contained in the North American Pollen Database. This suggests that, $6000 \mathrm{yr} \mathrm{BP}$, the mean July temperature was warmer by 1 to 2 degrees in Maritime Canada. This conclusion is in agreement with the results recently presented by Webb et al. (1993) for eastern North America.

\section{CONCLUSION}

A tentative map of the vegetation prevalent $6000 \mathrm{yr}$ BP in Maritime Canada is presented (Fig. 22). In northern New Brunswick, this vegetation was a mixed coniferous-deciduous forest with pine, mostly white pine (Pinus strobus). Fir (Abies) was present at high elevations and boreal forests grew on the New Brunswick Highlands. In the southern, central and eastern parts of the province, the forest type present was a mixed coniferous-deciduous forest with hemlock (Tsuga canadensis).

Prince Edward Island and mainland Nova Scotia were covered by a mixed coniferous-deciduous forest with hemlock. Cape Breton Island was covered by a mixed coniferous-deciduous forest with pine and/or fir except for the southern part of the Island, in contact with mainland Nova Scotia 6000 yr BP, where hemlock was probably present. Like today, hemlock did not grow too close to the coast where it was replaced by white pine (Pinus strobus).

Forest succession and sediment analysis indicate that, from circa 6500-6000 BP, a warm-dry period influenced the composition of the vegetation, possibly causing birch, shrubs and spruce to replace hemlock in Maritime Canada. This drier period, which may have been detrimental to hemlock, was favourable to white pine expansion as it reached its maximum Holocene range north of Chaleur Bay. This interpretation is in agreement with the results presented recently by Webb et al. (1993) for eastern North America.

\section{ACKNOWLEDGEMENTS}

This work has been made possible by the Green Plan and Global Change Funding. The Geological Survey of Canada Dating Laboratory provided a fair number of radiocarbon dates. Staff at Laboratoire Jacques-Rousseau, Université de Montréal, helped with the analysis of some of the pollen sequences. Alain Cloutier prepared the figures and helped with data entry and data handling. Thane Anderson and André Levesque, as critical readers, made useful suggestions that greatly improved the manuscript.

\section{REFERENCES}

Anderson, T.W., 1980. Holocene vegetation and climatic history of Prince Edward Island, Canada. Canadian Journal of Earth Sciences, 17:11521165 .

1985. Late-Quaternary pollen records from eastern Ontario, Quebec, and Atlantic Canada. In V.M. Bryant Jr. and R.G. Holloway, eds., Pollen Records of Late-Quaternary North American Sediments. The AASP Foundation, Dallas, 426 p.

Auer, V., 1930. Peat bogs in southeastern Canada, Canada Department of Mines. Geological Survey of Canada Memoir 162, 32 p.

Benninghoff, W.S., 1962. Calculation of pollen and spore density in sediments by addition of exotic pollen in known quantities. Pollen et Spores, 4: 232-233.

Davis, M.B., 1963. On the theory of pollen analysis. American Journal of Science, 261: 897-912.

1981. Outbreaks of forest pathogens in Quaternary history. Proceedings IV International Palynological Conference, Lucknow (197677), 3: 216-227.

Deevey, E.S. Jr., 1965. Sampling lake sediments by use of the Livingstone sampler. In B. Kummel and D. Raup, eds., Handbook of Paleontological Techniques. W.H. Freeman \& Co, San Francisco, 852 p.

Dyke, A. and Prest, V., 1987. Late Wisconsinan and Holocene history of the Laurentide Ice Sheet. Géographie physique et Quaternaire, 42: 237-263.

Energy, Mines and Resources Canada Geographical Map Series no. 11976

Environment Canada, 1989. Ecoclimatic regions of Canada. Ecological Land Classification series no. 23, 118 p.

Erdtman, G., 1960. The acetolysis method, a revised description. Svensk Botanisk Tidskrift, 54: 561-564.

Fawells, H.A., 1965. Silvics of forest trees of the United States. Agriculture Handbook No. 271. Forest Service, U.S. Department of Agriculture, $762 \mathrm{p}$.

Frankel, L. and Crowl, G.H., 1961. Drowned forests along the eastern coast of Prince Edward Island, Canada. Journal of Geology, 69: 352 357.

Green, D.G., 1976. Nova Scotian forest history: Evidence from statistical analysis of pollen data. Ph. D. Dissertation, Dalhousie University, $155 \mathrm{p}$.

Hadden, K.A., 1975. A pollen diagram from a postglacial peat bog in Hants County, Nova Scotia. Canadian Journal of Botany, 53: 39-47.

Hare, F.K. and Thomas, M.K., 1974. Climate Canada. John Wiley, Toronto, $256 \mathrm{p}$.

Jetté, H. and Mott, R.J., 1989. Palynostratigraphie du Tardiglaciaire et de l'Holocène de la région du lac Chance Harbour, Nouvelle-Écosse. Géographie physique et Quaternaire, 43: 27-38.

- in prep. Palynology of Island Lake, northern New Brunswick.

Jetté, H. and Richard, P.J.H., 1992: Contribution à I'histoire postglaciaire de la végétation en Gaspésie méridionale, Québec. Géographie physique et Quaternaire, 46: 273-284.

Korpijaakko, M.-L., 1977. On the origin and geobotanical development of muskeg in New Brunswick. Ph. D. Dissertation, University of New Brunswick, $154 \mathrm{p}$.

Livingstone, D.A., 1968. Some Interstadial and Postglacial pollen diagrams from Eastern Canada. Ecological Monographs, 38: 87-125.

Livingstone, D.A. and Estes, A.H., 1967. A carbon-dated pollen diagram from the Cape Breton Plateau, Nova Scotia. Canadian Journal of Botany, 45: $339-359$.

Livingstone, D.A. and Livingstone, B.G.R., 1958. Late-glacial and Postglacial vegetation from Gillis Lake in Richmond county, Cape Breton Island, Nova Scotia. American Journal of Science, 256: 341-359. 
Marie-Victorin, frère, 1964. Flore laurentienne. Presses de I'Université de Montréal, $924 \mathrm{p}$

Mott, R.J., 1971. Palynology of a buried organic deposit, River Inhabitants, Cape Breton Island, Nova Scotia. Report of Activities, Part B, Geological Survey of Canada, Paper 71-1: 123-125.

- 1975. Palynological studies of lake sediment profiles from southwestern New Brunswick. Canadian Journal of Earth Sciences, 12: 273 288 .

Mott, R.J., Grant, D.R., Stea, R. and Occhietti, S., 1986a. Late-glacial climatic oscillation in Atlantic Canada equivalent to the Allerød/Younger Dryas event. Nature, 323: 247-250.

Mott, R.J., Matthews, Jr., J.V. Grant, D.R. and Beke, G.J., 1986b. A late glacial buried organic profile near Brookside, Nova Scotia. Geological Survey of Canada, Current Research, Paper 86-1B, Part B: 289-294.

Ogden, J.G. III, 1960. Recurrence surfaces and pollen stratigraphy of a Postglacial raised bog, Kings County, Nova Scotia. American Journal of Science, 258: 341-353.

Ogden, K.F., 1980. An ice marginal lake in Annapolis Basin at the close of the late Wisconsin. B.Sc. thesis, Acadia University, 59 p.

1987. Vegetational and climatic history of Nova Scotia. I. Radiocarbon-dated pollen profiles from Halifax, Nova Scotia. Canadian Journal of Botany, 65: 1482-1490.

Osvald, H., 1970. Vegetation and stratigraphy of peatlands in North America. Acta Universitatus Upsaliensis, Nova Acta Regiae Societatis Scientiarum Upsaliensis, Uppsala, $96 \mathrm{p}$
Prinzen, S.E., 1990. A late-glacial diatom history of a bog on Brier Island Nova Scotia, with particular reference to the Younger Dryas climatic oscillation. Undergraduate thesis, Department of Biology, Queen's University, $45 \mathrm{p}$.

Railton, J.B., 1972. Vegetational and climatic history of southwestern Nova Scotia in relation to a South Mountain Ice Cap. Ph. D. dissertation, Dalhousie University, $146 \mathrm{p}$.

Rowe, J.S., 1972. Forest regions of Canada. Department of the Environment, Canadian Forestry Service Publication No. 1300, 172 p.

Stea, R.R. and Mott, R.J., 1988. Events of the Late Wisconsinan-Holocene transition in Nova Scotia. Abstracts, Geological Survey of America, 23rd Annual Meeting, 1988, 18031: 72

Terasmae, J., 1973. Notes on late Wisconsin and early Holocene history of vegetation in Canada. Arctic and Alpine Research, 5: 201-222.

1974. Deglaciation of Port Hood Island, Nova Scotia. Canadian Journal of Earth Sciences. 11: 1357-1365.

Walker, I.R. and Paterson, C.G., 1983. Post-glacial chironomid succession in two small, humic lakes in the New Brunswick, Nova Scotia (Canada) border area. Freshwater Invertebrate Biology, 2: 61-73.

Webb, T., III, Bartlein, P., Harrison, S.P. and Anderson, K.H., 1993. Vegetation, lake levels, and climate in Eastern North America for the pas 18,000 Years. In H.E. Wright, J.E. Kutzbach, T. Webb III, W.F. Ruddiman, F.A. Street-Perrott and P.J. Bartlein, eds., Global climates since the last glacial maximum. University of Minnesota Press, Minneapolis, 569 p.

\section{APPENDIX INFORMATION ON NEW SITES AND NEW DATES PRESENTED IN THIS STUDY}

- Island Lake, site 4 (Jetté and Mott, in prep.): lake $\left(47^{\circ} 49.5^{\prime} \mathrm{N}\right.$, $66^{\circ} 11^{\prime} \mathrm{W}$ ) located near the head of Chaleur Bay, about $40 \mathrm{~km}$ southeast of Campbellton, New Brunswick, at elevation $290 \mathrm{~m}$ a.s.I. The lake occupies a small kettle in an area of hummocky, stagnant ice topography and is located in the Appalachian Mountain region. The core was recovered by R.J. Mott in 1978. Dates: $5940 \pm 110$ (GSC-5620); $8650 \pm 100$ (GSC-3492); $12300^{*} \pm 210$ (GSC-2748); $9920 \pm 60$ (Beta-70672).

- Shaddick Lake, site 7: about $28 \mathrm{~km}$ west-northwest of Newcastle, New Brunswick $\left(47^{\circ} 05^{\prime} \mathrm{N}, 65^{\circ} 51.3^{\prime} \mathrm{W}\right)$, at elevation $44 \mathrm{~m}$ a.s.l. The core was recovered from a small kettle lake in an area of morainic topography by R.J. Mott in 1978. Dates: $6460 \pm 130$ (GSC-5621) and $10100 \pm 170$ (GSC-2767).

- Roulston Lake, site 11: lake $\left(46^{\circ} 53.5^{\prime} \mathrm{N}, 67^{\circ} 24^{\prime} \mathrm{W}\right)$ located in Tobique Valley at elevation ca. $155 \mathrm{~m}$ a.s.l. The Tobique River flows into the St.John River near town of Plaster Rock, New Brunswick. The core was recovered by R.J. Mott in 1978. Lake is a kettle hole in outwash plain associated with retreat of ice lobes up the Tobique River Valley. Basal part of the core has been published by R.J. Mott in 1986. New date (GSC-5639) obtained for this study. Dates: $5480 \pm 150$ (GSC-5639); $8150+130$ (GSC-3455); $9930 \pm$ 160 (GSC-2872) and $11100 \pm 90$ (GSC-2804).

- Bacon Lake, site 20: lake $\left(45^{\circ} 32^{\prime} \mathrm{N}, 66^{\circ} 27^{\prime} \mathrm{W}\right)$, located ca. 1.75 $\mathrm{km}$ north of Greenwich Centre, northwest side of Long Reach, North of Saint John, New Brunswick, at elevation ca. $90 \mathrm{~m}$. The lake lies in a depression between mountains and was sampled by
H. Jetté in 1989. Dates: $5080 \pm 140$ (GSC-5641); $8890 \pm 150$ (GSC-5032); $11300 \pm 240$ (GSC-5033); $13700 \pm 210$ (GSC-210).

- Poucette Lake, site 28: lake $\left(46^{\circ} 03^{\prime} \mathrm{N}, 64^{\circ} 17^{\prime} \mathrm{W}\right)$, located about $20 \mathrm{~km}$ northwest of Port Elgin, New Brunswick, at elevation $28 \mathrm{~m}$ a.s.I. The core was recovered by R.J. Mott in 1978. Dates: $5540 \pm$ 120 (GSC-5629); $9560 \pm 120$ (GSC-3462) and $10500 \pm 170$ (GSC2814).

- Wigmore Lake, site 29: lake $\left(45^{\circ} 44^{\prime} \mathrm{N}, 63^{\circ} 38^{\prime} \mathrm{W}\right)$, located about $5 \mathrm{~km}$ north of town of Leroy, Cumberland County, Nova Scotia, at elevation $73 \mathrm{~m}$ a.s.I. The core was recovered from a small, shallow lake in lowland between Northumberland Strait and Cobequid Highlands by R.J. Mott in 1990. Dates: $6590 \pm 179$ (Beta-66119); 11 $400 \pm 140$ (GSC-5567).

- Chance Harbour Lake, site 31: lake $\left(45^{\circ} 40^{\prime} \mathrm{N}, 62^{\circ} 37^{\prime} \mathrm{W}\right)$, located about $6.5 \mathrm{~km}$ north-northeast of Trenton, Nova Scotia, at elevation $12 \mathrm{~m}$ a.s.I. The core was recovered by $\mathrm{H}$. Jetté in 1985. Site published by $H$. Jetté and R.J. Mott in 1989. New date (Beta66127) obtained for this study. Dates: $2920 \pm 90$ (GSC-4394); $4850 \pm 70$ (GSC-4388); $6540 \pm 120$ (Beta-66127); $7050 \pm 100$ (GSC-4382); $9220 \pm 90$ (GSC-4573); $11300^{*} \pm 190$ (GSC-4274); $12100^{*} \pm 120$ (GSC-4267); 13 400* 160 (GSC-4328).

- Indian Lake, site 32 : lake $\left(45^{\circ} 30^{\prime} \mathrm{N}, 62^{\circ} 12^{\prime} \mathrm{W}\right)$, situated in highland area about $20 \mathrm{~km}$ southwest of Antigonish, Nova Scotia, at elevation $225 \mathrm{~m}$ a.s.I. The core was recovered by R.J. Mott in 1991. Dates: $5690 \pm 150$ (Beta-66121); $9856 \pm 130$ (GSC-5347); $11600 \pm 170$ (GSC-5293). 
- Pye Lake, site 33: lake $\left(45^{\circ} 05^{\prime} \mathrm{N}, 62^{\circ} 00^{\prime} \mathrm{W}\right)$, located approximately $.75 \mathrm{~km}$ northwest of Marie Joseph, Nova Scotia, at elevation ca. $15 \mathrm{~m}$. asl. The core was recovered by R.J. Mott in 1990 . Dates: $1140 \pm 080 ; 4440 \pm 090 ; 8120 \pm 140 ; 10000 \pm 160$ (GSC5249); $10800 \pm 190$ (GSC-5242); $12200 \pm 220$.

- Bower Lake, site 42 : small lake $\left(44^{\circ} 05^{\prime} \mathrm{N}, 65^{\circ} 47^{\prime} \mathrm{W}\right)$, located just west of East Kemptville, and about $15.5 \mathrm{~km}$ NE of Carleton, Nova Scotia, at elevation $73 \mathrm{~m}$ a.s.I. The lake is situated on granite terrane covered by glacial deposits and was sampled by R.J. Mott in 1989. Dates: $5930 \pm 110$ (Beta-66129); $9820 \pm 160$ (GSC-5022); $10700 \pm 170$ (GSC-5023); $12400 \pm 220$ (GSC-5024).
- Timber Lake, site 45 : lake $\left(46^{\circ} 23^{\prime} \mathrm{N}, 60^{\circ} 40^{\prime} \mathrm{W}\right)$, located approximately $7 \mathrm{~km}$ northwest of Tarbot Cape Breton Island, Nova Scotia, at elevation about $386 \mathrm{~m}$ asl. The core was recovered from a small, relatively shallow lake on southern Cape Breton Highlands by R.J. Mott in 1990. Dates: $5340 \pm 130$ (Beta-66130); $11200 \pm$ 200 (GSC-5259).

- MacLaughlin Pond, site 53: lake basin $\left(46^{\circ} 22^{\prime} \mathrm{N}, 62^{\circ} 50^{\prime} \mathrm{W}\right)$, located in a clay-sand-dominated ground moraine at elevation $30 \mathrm{~m}$ a.s.I. Core collected by T. Anderson and R.J. Mott in 1978. Pollen diagram in Anderson (1985). Dates: $2080 \pm 130 ; 3660 \pm 80 ; 5060$ $\pm 90 ; 6350 \pm 80 ; 8050 \pm 100 ; 9670 \pm 130$. 